Research Article/Araştırma Makalesi

\title{
A Qualitative Research: Evaluation of Applied Children's Literature Course Activities
}

\author{
Kismet DELIVELI *1 (iD \\ ${ }^{1}$ Muğla Sıtkı Koçman University, Faculty of Education, Muğla, Turkey, dkismet@mu.edu.tr \\ * Corresponding Author: dkismet@mu.edu.tr
}

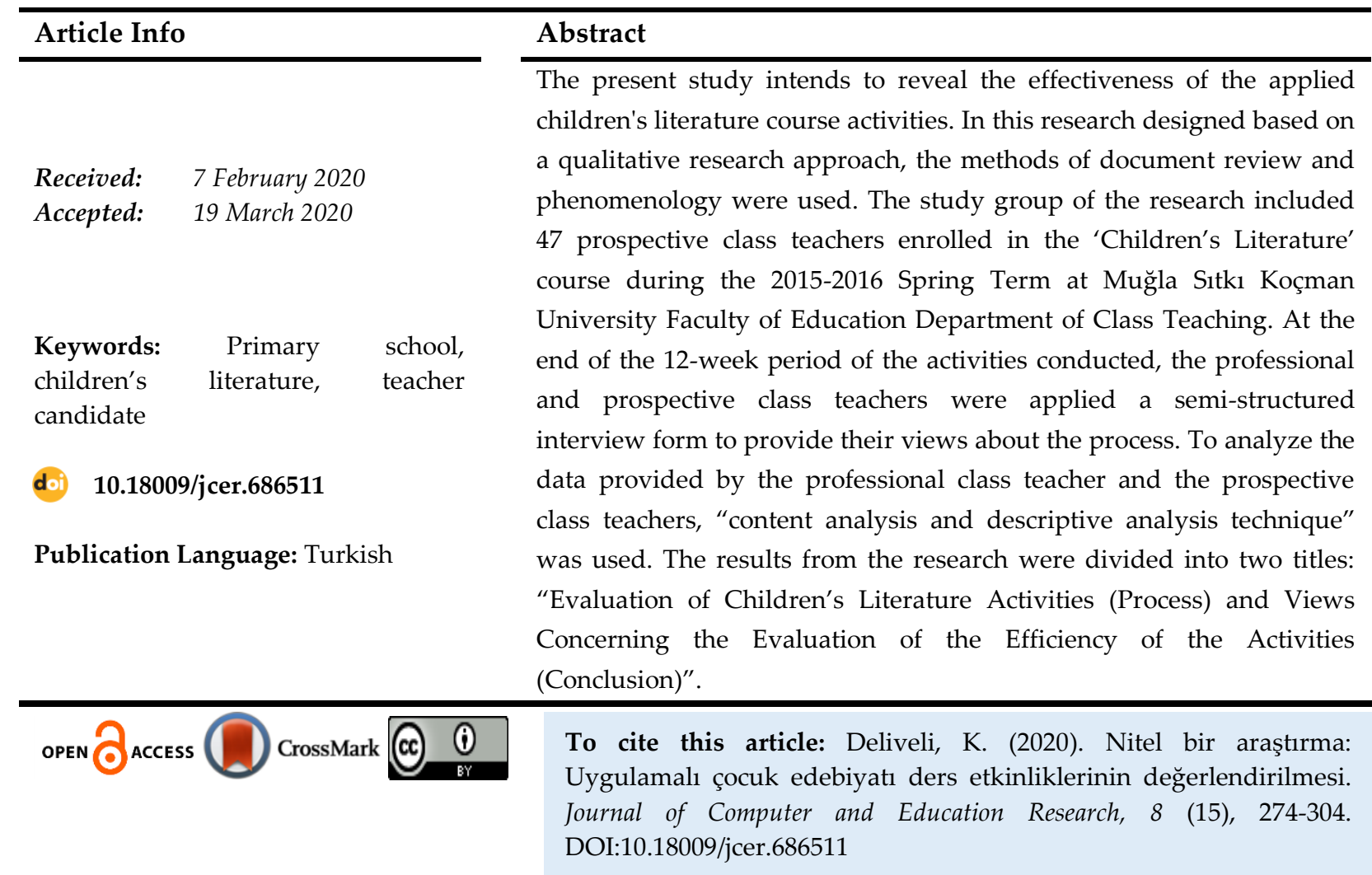

\section{Nitel Bir Araştırma: Uygulamalı Çocuk Edebiyatı Ders Etkinliklerinin Değerlendirilmesi}

\begin{tabular}{|c|c|}
\hline Makale Bilgisi & Öz \\
\hline & $\mathrm{Bu}$ çalışmanın amacı uygulamalı çocuk edebiyatı ders etkinliklerinin \\
\hline 7 Şubat 2020 & etkililiğini ortaya koymaktır. Nitel araştırma yaklaşımına göre \\
\hline 19 Mart 2020 & tasarlanan bu araştırmada doküman incelemesi ve fenomenoloji \\
\hline & yöntemleri kullanılmıştır. Araştırmanın çalışma grubunu 2015-2016 \\
\hline & Bahar dönemi Muğla Sıtkı Koçman Üniversitesi, Eğitim Fakültesi Sınıf \\
\hline $\begin{array}{l}\text { Anahtar kelimeler: İlkokul, çocuk } \\
\text { edebiyatı, öğretmen adayı }\end{array}$ & $\begin{array}{l}\text { Öğretmenliğinde okuyan ve "Çocuk Edebiyatı" dersi alan } 47 \text { sınıf } \\
\text { öğretmeni adayı oluşturmaktadır. } 12 \text { haftanın sonunda etkinlikler }\end{array}$ \\
\hline & tamamlandığında sınıf öğretmeni ve öğretmen adaylarına yarı \\
\hline doi) $10.18009 /$ jcer. 686511 & $\begin{array}{l}\text { yapılandırılmış görüşme formu uygulanarak sürece yönelik görüşleri } \\
\text { istenmiştir. Sınıf öğretmeni ve öğretmen adaylarının görüşlerinden elde }\end{array}$ \\
\hline Yayım Dili: Türkçe & edilen verilerin çözümlenmesinde "içerik analizi ve betimsel analiz \\
\hline & tekniği" kullanılmıştır. Araştırma bulguları, "Çocuk Edebiyatı \\
\hline & Etkinliklerinin Değerlendirilmesi (Süreç) ve Etkinliklerin Etkililiğinin \\
\hline & Değerlendirilmesine Yönelik Görüşler (Sonuç)” olmak üzere iki başlık \\
\hline & altında incelenmiştir. \\
\hline
\end{tabular}




\section{Summary}

\section{A Qualitative Research: Evaluation of Applied Children's Literature Course Activities}

\section{Introduction}

The subject of how to administer children's education has recently changed as humankind's social and individual aspects were explored. Particularly, the changes occurring in education and education psychology have been effective in changing the perspective concerning how children's education should be administered (Baş, 2015; Güleryüz, 2006; Oğuzkan, 2010). Unlike the adult literature, children's literature, which is intended to meet children's needs, emerged to answer the questions asked concerning children's education. A sub-branch of literature, children's literature has therefore achieved a significant position in children's education since it addresses children's world, helps children realize themselves, contributes to their language improvement, and is intended not only to educate children but also help them read regularly so they can explore new worlds (Gönen, \& Veziroğlu, 2017).

The current study is intended to reveal the effectiveness of the activities employed within the applied children's literature course. To this end, prospective teachers participating in the application have helped answer the below-mentioned questions;

a. What is the nature (process) of the studies they prepared in children's literature?

b. What are the evaluations of the prospective teachers and the observer teacher (result) for the effectiveness of the activities?

The study intends to reveal to what extent the prospective class teachers are aware of the objectives of Children's Literature course while also qualitatively evaluating the works the prospective class teachers prepared for 3rd grade primary school students and applied as part of the study. To conclude the study, both prospective teachers and professional class teachers were interviewed concerning the efficiency of the "Children's Literature" activities administered within the Turkish Language course for $3^{\text {rd }}$ grade primary school students. This is also intended to prove the effects of the activities administered by the prospective teachers using their lesson plans they prepared for $3^{\text {rd }}$ grade primary school teachers in a way 
incorporating "types of Children's Literature' in improving students" communication skills and making sure that students are active during classes.

\section{Method}

Designed using the qualitative research approach, the study used methods of document review and phenomenological research. To prove the effectiveness of the works administered by the prospective teachers within the framework of children's literature, these works were evaluated using document assessment method; and the prospective teachers and the professional teachers were interviewed to make the final assessment. The study group included 47 prospective class teachers including 26 from $2 \mathrm{~A}$ and 21 from $2 \mathrm{~B}$, all studying at Muğla Sitkı Koçman University Faculty of Education Department of Class Teaching and enrolled in the "Children's Literature" course during the 2015-2016 Spring Term. Conducted in a primary school in the central district of Muğla, the activity was administered in the Turkish Language class of the class teacher who intends to improve students' communication skills and supports the study on a voluntary basis. The activities were planned to be administered for 12 weeks under the guidance of a lecturer and the supervision of the class teacher. It was applied in 34 primary school classrooms each composing 14 students. Before deciding the activities to be administered at the school, in line with the study objective, the prospective class teachers were informed about the objectives and genres of children's literature, as well as about what kinds of activities can be administered for each genre. Given 2-week-long period to prepare activities based on the objectives of the Children's Literature course, the prospective class teachers designed activities on 'Fable, Fairy Tale, Saga, Tale, Memoir, Travel Writing, Poem, Works on Scientific, Invention and Natural Phenomena, Children's Newspaper and Magazines'. The prospective teachers were continuously provided with feedback on such topics as 'selection of methods and techniques in line with the objectives set, creation of visual and audial materials by the teachers, and evaluation of the process in terms of the objectives set'. In the Children's Literature course, the prospective teachers presented the lesson plans and the materials they prepared before applying them in class; and they updated their lesson plans in terms of 'objectives, method, content and assessment' accordingly based on the recommendation provided by the course lecturer and their peers in their class. The prospective teachers prepared a selection of proper samples of 'Fables, Fairy Tales, Sagas, Tales, Memoirs, Travel Writings, Poems, and Works on Scientific, Invention and Natural 
Phenomena' for the activities that are intended to introduce genres of children's literature during the first ten weeks, and subsequently during the 11th and 12th weeks, they administered "Class Newspaper and Magazine Preparation Activity" to raise an interest of reading in children. The professional class teacher and the prospective class teachers were asked to provide their views about the process through a semi-structured interview form at the end of the 12-week period. To analyze the data obtained through interviewing the professional class teacher and the prospective class teachers, 'content analysis and descriptive analysis technique' was used.

\section{Findings and Discussion}

The findings from the research were divided into two titles: “Evaluation of Children's Literature Activities (Process) and Views Concerning the Evaluation of the Efficiency of Children's Literature Activities (Conclusion)". The analysis made on the activities revealed that they were in accordance with the objectives of the 'Children's Literature' course, as well as that the prospective teachers made use of different methods and techniques on the activities, and that they were able to assess the levels of students in terms of the objectives set. The views concerning the efficiency of the Children's Literature activities revealed that the prospective teachers successfully administered the activities prepared by each of them, they were careful about using efficient and different materials and able to raise an interest in the class and communicate with the children, as well as that almost each and every child developed an interest in the genres of "Children's Literature", thereby showing improved motivation to read. It is also understood that the prospective teachers enjoyed administering the activities and found them useful, as well as that they express both the students in class and themselves were happy to have been able to be involved in an informative and entertaining process. 


\section{Giriş}

Çocuk eğitiminin nasıl gerçekleştirilmesi gerektiği konusu günümüzde insanın toplumsal ve bireysel yönlerinin bilinmesiyle birlikte değişime uğramıştır. Özellikle eğitim ve eğitim psikolojisi alanındaki gelişmeler çocuk eğitimin nasıl olması gerektiğiyle ilgili bakış açısının değişmesinde etkili olmuştur. Çocuk eğitimindeki arayışlar ise çocuk edebiyatının doğmasında etkili olmuştur (Baş, 2015; Güleryüz, 2006; Oğuzkan, 2010). Böylece çocuğun dünyasına hitap eden, kendini gerçekleştirmesine yardım eden, dilsel gelişimine katkıda bulunan, çocuğu sadece eğitmeyi değil, okuma alışkanlığı kazandırmayı ve yeni dünyalar keşfetmesini amaçlayan çocuk edebiyatı yetişkinlerin edebiyatından farklı olarak edebiyatın bir alt dalı olarak çocuk eğitiminde önemli bir konuma yerleşmiştir (Gönen, \& Veziroğlu, 2017).

Çocuk edebiyatı "erken çocukluk döneminden başlayarak ergenlik dönemini de içeren bir yaşam evresinde çocukların anlama düzeylerine uygun olarak hazırlanan ve dil gelişimini destekleyerek sanatsal niteliği olan dilsel ve görsel iletilerle duygu ve düşünce dünyalarını zenginleştiren ürünlerin genel adıdır"' (Sever, 2003, s. 9). Güleryüz'e (2006, s. 33) göre "Dünyamızın anlaşılması, yorumlanması ve değiştirilmesi için çocukluk ruhuna ihtiyaç vardır. Çocuk Edebiyatı, uygarlığın gelişim seyri içerisinde insanlığın ürettiği 'sözlü ve yazılı' sanat ürünlerinden oluşan büyük bir çiçek bahçesine benzetilebilir. Bu edebiyat üst düzey sözlü (oyun, beden dili), yazılı (görsel sanat) ürünleri üzerine yapılan çalışmaları kapsar". Çocuk Edebiyatı'nın anlaşılması için bu deyimi oluşturan "edebiyat ve çocuk" kavramlarının bakılması gerektiğine işaret eden Oğuzkan'a (2010, ss. 1-3) göre bu edebiyat alanı yetişkinler edebiyatından farklı şekilde ele alınmalıdır. Buna göre çocuk iki yaşından ergenlik dönemine kadar süren büyüme dönemi içinde bulunan insan yavrusu olarak ele alınabilir. Edebiyat ise duygu ve hayallerin, söz ve yazı halinde, güzel ve etkili bir şekilde anlatılması sanatıdır. İki kavram birleştirildiğinde, çocuk edebiyatı 2-14 yaş arasında çocuk olarak tanımlanan bireylerin gereksinimlerini karşılayan edebiyat alanı olarak tanımlanabilir. Aynı görüşü benimseyen Yalçın ve Aytaş'a (2005) göre çocuk edebiyatı çocukların psikolojik ve bedensel gelişimlerine uygun, onlara hitap eden, basitlikten uzak, çocuğun analiz ve sentez yapmasına imkân tanıyan, sözlü ve yazılı edebi ürünlerin tamamidir.

Çocuk edebiyatı kapsamının daha iyi anlaşılması için, bu edebiyat kapsamında ele alınan türlere bakmakta yarar vardır. Nicelik ve nitelik bakımından günümüzde çok gelişmiş 
olan çocuk edebiyatı, ninniler, bilmeceler, tekerlemeler, yakıştırmacalar, türküler, çocuk oyunları, masallar, hikâyeler, mitler, efsaneler, destanlar, şiirler, öyküler gibi çocuksu bir anlatımla sunulan türleri içerisinde barındırmaktadır (Sınar, 2006; Şimşek, 2002). Genel olarak çocuk edebiyatı türlerinin çocukların hayal, duygu ve düşüncelerini besleyen dilsel gelişimini etkileyen önemli işlevleri yanında her bir türün çocuğa kazandıracağı önemli işlevleri vardır. Örneğin insanoğlu ezgi ile söylenen ninniler yoluyla edebiyatın ilk ürünleri ile bebeklik döneminde tanışmaktadır. Çocukluk döneminde dili kullanma becerileri geliştiren türkü gibi ezgi ile söylenen şiirler, bilmeceler, sayışmacalar, yakıştırmacalarla tanışırken, benzer sesli hecelerden oluşan sözleri içeren tekerlemeler yoluyla dilin kafiye ve üslup özelliklerini fark etmeye başlamaktadır (Güleryüz, 2006). Bu dönemde içinde doğduğu dünyayı anlamaya çalışırken çocuk edebiyatının ilk ürünleri olan masal, fabl ve öykülerle de tanışmaktadır. Okunan masal ya da öykü kimi zaman eleştirmeyi kimi zaman doğru yanlışı ayırt etmeyi öğrenirken kendine model oluşturacak davranışları benimseyerek özdeşim kurmaktadır. Okul çağında ise masallar, hikâyeler, destanlar, efsaneler, şiirler, gezi yazıları, biyografik eserler, fen ve doğa eserlerini anlatan eserlerle tanışan çocuk, kimi zaman farklı dünyalara zamanda ve mekânda yolculuk ederken evreni, insanı ve kendini keşfetmektedir. Çocuk edebiyatı türleri yoluyla çocuk sadece yeni bilgiler de öğrenmekle kalmayıp bazı değerleri de öğrenmektedir. Bu yönüyle çocuk edebiyatının çocuğun sadece bilişsel süreçlerinde değil, sosyal gelişim, kişilik gelişimi ve dil gelişimine etkisi olduğu söylenebilir. Ayrıca çocukların iç dünyalarını zenginleştirerek duygularını, düşüncelerini, hayallerini besleyen çocuk edebiyatının çocukların yaratıcı yeteneklerinin geliştirilmesinde ve desteklenmesinde de önemli işlevleri bulunduğu (Güleryüz, 2006; Oğuzkan, 2010; Şimşek, 2002) ve bu yönüyle de çocuk edebiyatının çocukların bilişsel gelişimlerine olumlu etkisinin olduğu ileri sürülebilir.

Çocukların doğal gereksinimleri yanında öz bakımından hiç değişmeden sürüp gidecek olan birtakım ruhsal gereksinimleri bulunmaktadır. $\mathrm{Bu}$ gereksinimlerin karşılaşmasında sözlü ve yazılı edebiyat eserleri büyük rol oynamaktadır (Bağcl, 2007, s. 118). Güleryüz' e (2006, s. 35) göre çocuk edebiyatının doğası gereği beslendiği alanlar vardır. Bu alanlar toplum, birey, doğa, felsefe ve evrenle kurulan ilişkiler şeklinde ele alınabilir. Bu konuda açıklamaları aşağıdaki gibidir (Güleryüz, 2006, ss. 35-37):

“Toplumun kültürel yapısı çocuğun dünyayı algılayış biçimlerini etkiler. Çocuk edebiyatı ürünleri, bu toplumsal yapıya göre biçim alır, bu yapıyı biçimlemek ve yeniden yapılandırmak için de bir araç işlevi görür. İnsanın davranışlarını ve yaşamın biçimlendiren doğa aynı zamanda insanoğlunun keşfetmeye çalıştı̆̆ gü̈çtür. 
Bireysel anlamda çocuk edebiyatı çocuğun birey olarak kendini tanımasına yardımcı olduğu gibi kültürel bir çerçeve de oluşturur. Çocuk edebiyatı, çocuğun düşünme becerilerini ve yaratıcllı̆̆ın geliştirirken, çocuğun değer yargıların oluşturmasina katkıda bulunur. Edebiyat ürünleri, insanliğın oluşturduğu değerlerden yararlanarak, üst düzey düşünsel bireşimler sonucunda oluşur. Toplumlarm ve insanlarm bu değerlere katkı yapma görevleri olduğu gibi, bu değerlerden yararlanma hakları da vardır ki bu da çocuk edebiyatının evrensel boyutu oluşturur."

Anlaşılacağı üzere 2-14 yaş çocuklarının hayal, duygu ve düşüncelerine yönelik sözlü ve yazılı tüm eserleri içine alan çocuk edebiyatı ürünleriyle çocuğa doğru davranış kalıplarını öğretme ve onu hayata hazırlama amacı güdülmektedir. Çocuk edebiyatı ürünleriyle çocuğa toplum içinde uyması gereken kuralları öğretilebilir. Sadece toplumsal açıdan değil, evrensel açıdan geçerli olan iyilik, dürüstlük, yardımlaşma gibi temel değerler kazandırabilir (Arseven, 2005; Oğuzkan, 2010). Dolayısıyla çocuk edebiyatı ürünlerinin çocuğun ulusal ve evrensel değerler üzerine düşünmesini sağlama yönünden önemli bir yeri olduğu gibi (Güleryüz, 2006), sosyal beceriler edinmesi, dil ve iletişim becerilerini geliştirilmesi anlamında da önemli işleve sahip olduğu ileri sürülebilir (Kıbrıs, 2010). Dolayısıyla çocukların düş kurma, düşünme becerilerini destekleyecek olan çocuk edebiyatı ürünleri doğumdan başlayarak her gelişim döneminde eğitim amaçlı kullanılabilir (Oğuzkan, 2010; Sawyer, 2012; Sever, 2003).

Çocuklar dilsel becerileri okul dışı ortamlarda olumlu ya da olumsuz şekilde gelişigüzel öğrenebilir. Yine sosyal ortamlar da gözlem ve taklit yoluyla olumlu davranışlar yanında olumsuz davranışlar da geliştirebilir. Oysa okullarda dilsel beceriler sistemli bir şekilde öğretilirken, sosyal açıdan da toplumun beklediği olumlu ve istendik davranışlar çocuklara kazandırılmaya çalışılmaktadır. Bu açıdan okul döneminde sosyalleşmeleri, kendilerini daha iyi ifade etmeleri ve iletişim becerilerinin geliştirilmesi anlamında çocuklara istendik davranışların kazandırılması hedefleniyorsa Türkçe dersinde çocuk edebiyatı türlerini içine alan, oyun-etkinlik ağırlıklı farklı uygulamalara yer verilmesi yararlı olabilir. Lisans düzeyinde de öğretmen adayları yetiştirilirken çocuk edebiyatı dersi teorik işlenmeyip, özellikle Türkçe dersinde çocuk edebiyatından nasıl yararlanabileceklerine konusunda uygulamalı eğitim verilmesi, öğretmen adaylarının mesleki bilgiler yanında tecrübeler edinmeleri anlamında etkili olabilir.

Literatürde çocuk edebiyatı çalışmalarına bakıldığında 1980'lere kadar lisansüstü araştırmalarda konu olmadığı anlaşılmaktadır (Balta, 2019; Balc1, 2012). Kapsamı değerlendirebilmek için Türkiye'de yapılan çocuk edebiyatı üzerine hazırlanan lisansüstü 
tezleri inceleyen Balcı'nın (2012) araştırma sonuçlarına bakıldı̆̆ında araştırmacıların çoğunlukla çocuklar için hazırlanan eserleri değerlendirmeye yönelik çalışmalar yaptıkları anlaşılmaktadır. Ayrıca 1981-2010 yılları arasında Türkiye'de yapılan lisansüstü araştırmalarda, araştırmacıların en çok edebi tür incelemesi yaptıkları, daha çok çocuk edebiyatı ve çocuk eğitimi, çocuk edebiyatı yazarları, çocuk gazete ve dergileri, görsel unsurlar ile resimleme konularını tercih ettikleri görülmektedir. 2006- 2010 yılları arasında önceki dönemlere kıyasla çocuk edebiyatı alanında yapılan tezlerde "çocuk edebiyatı ve Türkçe eğitimi” konusunun daha fazla ele alındığı sonucuna ulaşılmaktadır (Balcı, 2012, ss.200-202).

Balta'nın (2019) yaptığı bir başka araştırma sonuçlarına göre, 2011-2018 yılları arasında çocuk edebiyatı üzerine yapılmış lisansüstü çalışmalar değerlendirildiğinde özellikle çocuk edebiyatı odaklı lisansüstü tezlerde 2017'ye kadar artışlar olduğu anlaşılmaktadır. Bu tezlerde ise daha çok değer aktarımı ve eğitselliğe ağırlık verildiği, yöntem olarak nitel yöntemin tercih edildiği görülmektedir. Ayrıca çocuk edebiyatı ile ilgili konularının sıklıkla Türkçe eğitimi bilim dalında çalışıldığı anlaşılmaktadır.

Gerek çocuk edebiyatı konulu bibliyografya çalışmalarına bakıldığında (Altunya, 2012) gerekse çocuk edebiyatı konulu bilimsel çalışmaları değerlendiren araştırmacıların araştırma bulguları (Sınar, 2006; Balc1, 2012) değerlendirildiğinde çocuk edebiyatı ve çocuk eğitimi konulu çalışmaların daha fazla yapılması gerektiği görülmektedir. Çocuk edebiyatının derslerde eğitim amaçlı kullanımı konusunda yapılan çalışmalar incelendiğinde Türkçe eğitimi konusunda çalışmaların ön plana çıktı̆̆ı görülmektedir (Balta, 2019). Türkçe eğitimi ve çocuk edebiyatı konulu çalışmalar incelendiğinde ise araştırmacıların (Sınar, 2006; Altunkaya, 2012) özellikle Türkçe eğitiminde çocuk edebiyatından yararlanılmasının önemine dikkat çektikleri anlaşılmaktadır. Bu çalışmada ise sınıf öğretmeni adaylarına lisans düzeyinde verilen çocuk edebiyatı dersi teorik ve uygulamalı bir şekilde işlenerek, ders kapsamında öğretmen adaylarının hazırladıkları etkinliklerin uygulamadaki etkililiği araştırılmak istenmiştir.

\section{Araştırmanın Amacı ve Önemi}

Bu çalışmanın amacı, sınıf öğretmeni adaylarına verilen uygulamalı çocuk edebiyatı dersinin uygulamadaki etkililiğini ortaya koymaktır. Bu amaca bağlı olarak bu araştırma kapsamında uygulamaya katılan öğretmen adaylarının; 
a. Çocuk edebiyatı dersinde hazırladıkları çalışmaların niteliği (süreç) nedir?

b. Uyguladıkları etkinliklerin etkililiğine ilişkin öğretmen adayları ve gözlemci öğretmeninin (sonuç) değerlendirmeleri nasıldır? sorularına yanıt aranmıştır.

Araştırmanın süreç değerlendirmeleri kısmında sınıf öğretmeni adaylarının ilkokul öğrencileri için 3.sınıf düzeyinde Türkçe dersi için hazırlayıp uyguladıkları çocuk edebiyatı etkinliklerinin niteliği değerlendirilirken; öğretmen adaylarının çocuk edebiyatı dersinin amaçlarının ne kadar farkında oldukları belirlenmeye çalışılmıştır.

Sonuç değerlendirmelerinde ise Türkçe dersinde uygulanan çocuk edebiyatı etkinliklerinin etkililiği konusunda hem öğretmen adayları ve hem de sınıf öğretmeninin görüşleri alınmıştır. Bu yolla öğretmen adaylarının ilkokul 3. sınıf düzeyinde Türkçe dersinde çocuk edebiyatı türlerine uygun olarak tasarlayıp uyguladıkları etkinliklerin gerek öğrencilerin iletişim becerilerini geliştirmeye ve gerekse öğrencilerin derse katılımlarını sağlamaya etkileri ortaya konulmaya çalışılmıştır. Dolayısıyla sınıf öğretmeni adaylarının mesleki bilgiler yanında uygulamaya yönelik beceriler geliştirmelerini amaçlayan bu araştırma bulguları, öğretmen adaylarının uygulamalar sırasında ne tür deneyimler kazandıklarının anlaşılması ve çocuk edebiyatı türlerinin ilkokul 3. sınıf düzeyinde Türkçe dersinde eğitim amaçlı kullanılabileceğine örnek oluşturması bakımından önemlidir.

\section{Yöntem}

Nitel araştırma yaklaşımının benimsendiği bu çalışmada doküman incelemesi ve fenomenoloji yöntemlerinden yararlanılmıştır. Üzerinde durulan olay/konuyu tecrübe eden kişilerin görüşlerinden veri toplanmasına imkân veren nitel araştırmanın amacı sosyal dünyanın aktörleri olarak insanların algıladıkları dünyayı nasıl yorumladıklarını ortaya koymaktır. Bu yönüyle nitel araştırmalar dünyayı görünür hale getiren bir dizi yorumlayıcı materyalin kullanımına imkân veren bir yaklaşımdır. Bu yaklaşımda araştırmacı "saha notlarını, görüşmeleri, konuşmaları, fotoğrafları ve kayıtları ya da notları" temsiller serisine dönüştürebilmektedir (Yıldırım \& Şimşek, 2013). Nitel araştırmalarda kullanılan doküman incelemesi yöntemi araştırılan konu ile ilgili yazılı materyaller incelenmesine olanak vermektedir. Bu yöntem özellikle eğitim araştırmalarında öğrenci çalışmaları, raporları ve notları incelenirken kullanılabilmektedir (Yıldırım \& Şimşek, 2013). Fenomolojik yöntemde ise araştırmacı doğal ortamında olup bitenleri incelerken insanların olup bitenlere verdiği anlamı onların bakış açısından değerlendirmeye çalışır (Creswell, 2014). Bu yöntem ile araştııılan fenomenle ilgili olarak insanların ne algıladıkları, ne anladıkları ve 
deneyimlerinin neler olduğu anlaşılması amaçlandığından (Creswell, 2014; Yıldırım \& Şimşek, 2013) bu araştırmada çocuk edebiyatı dersi etkinlikleri kapsamında uygulamaya katılan öğretmen adaylarının uygulama sırasında neler deneyimledikleri ortaya konulmaya çalışılmıştır. Uygulamayı gözlemleyen sınıf öğretmeninin görüşlerine başvurulmak suretiyle de sınıf öğretmenin çocuk edebiyatı etkinlikleri ile ilgili düşünceleri değerlendirilmek istenmiştir.

\section{Çalışma Grubu}

Öğretmen adaylarından oluşan çalışma grubunu 2015-2016 bahar dönemi'nde Muğla Sıtkı Koçman Üniversitesi Eğitim Fakültesi Sınıf Öğretmenliği Anabilim Dalında öğrenim gören ve çocuk edebiyatı dersini alan 47 öğrenci oluşturmuştur. Etkinlikte görev alacak gönüllü öğretmen adaylarına ulaşılırken amaçlı örnekleme yöntemlerinden benzeşik örnekleme yönteminden yararlanılmıştır (Yıldırım \& Şimşek, 2013).

Tablo 1. Çalışma gurubunda yer alan öğretmen adayları

\begin{tabular}{lll}
\hline \multicolumn{1}{c}{ Şube } & K1z & Erkek \\
\hline Sinıf Öğretmenliğ̀i 2A & 19 & 7 \\
Sinıf Öğretmenliği 2B & 15 & 6 \\
Toplam sayı & 34 & 13 \\
\hline
\end{tabular}

Çocuk edebiyatı etkinliklerinde görev alacak öğretmen adayları belirlenirken 2A ve 2B şubesi olmak ayrı ayrı olmak üzere 3-4 kişilik gruplar oluşturulmuş, 2A ve 2B sınıf öğrencileri toplam 24 etkinlik planı hazırlayıp, uygulamıştır. Uygulamaya 2A şubesinden 19 kız, 7 erkek; 2B şubesinden de 15 kız, 6 erkek öğrenci katılmıştır.

\section{Verilerin Toplanması ve Analizi}

Uygulamalar başlamadan önce uygulama yapılacak okulu ve sınıfı tanımak amacıyla okul müdürü ve sınıf öğretmeniyle görüşmeler yapan ders öğretim elemanı, araştırmayı gönüllü olarak destekleyen sınıf öğretmenine çalışmanın kapsamı ile ilgili bilgiler vermiştir. Bu görüşmeler sırasında sınıf öğretmeninin Türkçe dersinde çocukların iletişim becerilerini geliştirecek uygulamalar yapılmasının yararlı olacağını bildirmesi üzerine, ders öğretim elemanı sınıf öğretmeninin Türkçe ders etkinliklerinde çocuk edebiyatı türlerinden nasıl yararlandığını görmek üzere 2 saat süreyle gözlem yapmıştır. 
Çocukların iletişim becerilerini geliştirmek üzere ne tür etkinlikler yapılabileceği konusunda karşılıklı görüş alışverişin yapıldığ 1 ikinci görüşme sonrası, ders öğretim elemanı önerisiyle sınıf öğretmeni sınıfında bulunan öğrencilere öğrencilere "sosyometri tekniği ve kimdir bu?" tekniğini uygulamıştır. 14 kişilik bu öğrenci grubunun akranlarıyla olan iletişim biçimlerinin incelendiği sonuçlar analiz edildikten sonra, sınıf öğretmeni ile paylaşılmıştır. Aşağıda Tablo 2'de ve Şekil 1'de sosyometri ölçüm sonuçları incelenebilir.

Tablo 2. Sosyometri ölçeği sonuçları

\begin{tabular}{|c|c|c|c|c|c|c|c|c|c|c|c|c|c|c|c|}
\hline \multirow[t]{2}{*}{$\mathrm{NO}$} & \multirow{2}{*}{$\begin{array}{l}\text { SEÇEN } \\
\begin{array}{l}\text { Öğrenci } \\
\text { Kodu }\end{array}\end{array}$} & \multicolumn{14}{|c|}{ SEÇILEN } \\
\hline & & D-E & E-E & E-K & Be-K & P-E & El-K & S1-K & $\mathrm{Y}-\mathrm{K}$ & Se-K & M-E & G-K & F-K & A-K & $\mathrm{Y}-\mathrm{K}$ \\
\hline \multirow{2}{*}{1} & \multirow[t]{2}{*}{ D-E } & & & & 2 & & & & & & 1 & & & & \\
\hline & & & & & & & & & & & & & & & \\
\hline \multirow{2}{*}{2} & \multirow[t]{2}{*}{ E-E } & & & & 1 & & 2 & & & & 3 & & & & \\
\hline & & & & & & & & & & & & & & & \\
\hline \multirow{2}{*}{3} & \multirow[t]{2}{*}{ E-K } & & & & 3 & & & & 2 & & 1 & & & & \\
\hline & & & & & & & & & & & & & & & \\
\hline \multirow{2}{*}{4} & \multirow[t]{2}{*}{ Be-K } & & 1 & & & & 3 & & 2 & & & & & & \\
\hline & & & & & & & & & & & & & & & \\
\hline \multirow{2}{*}{5} & \multirow[t]{2}{*}{ P-E } & & 1 & & 3 & & 2 & & & & & & & & \\
\hline & & & & & & & & & & & & & & & \\
\hline \multirow{2}{*}{6} & \multirow[t]{2}{*}{ El-K } & & 2 & & & & & & 1 & & 3 & & & & \\
\hline & & & & & & & & & & & & & & & \\
\hline \multirow{2}{*}{7} & \multirow[t]{2}{*}{ S1-K } & & 1 & & 3 & & 2 & & & & & & & & \\
\hline & & & & & & & & & & & & & & & \\
\hline \multirow{2}{*}{8} & \multirow[t]{2}{*}{ Y-K } & & 2 & & 3 & & 1 & & & & & & & & \\
\hline & & & & & & & & & & & & & & & \\
\hline \multirow{2}{*}{9} & \multirow[t]{2}{*}{ Se-K } & & & 2 & & & & & & & 3 & 1 & & & \\
\hline & & & & & & & & & & & & & & & \\
\hline \multirow{2}{*}{10} & M-E & 1 & & & & & & & & & & & & & \\
\hline & & & & & & & & & & & & & & & \\
\hline 11 & G-K & & 1 & & 3 & & 2 & & & & & & & & \\
\hline 11 & & & & & & & & & & & & & & & \\
\hline & F-K & & 2 & & & & & & 1 & & & 3 & & & \\
\hline 12 & & & & & & & & & & & & & & & \\
\hline & A-K & & 1 & & 3 & & 2 & & & & & & & & \\
\hline 13 & & & & & & & & & & & & & & & \\
\hline 14 & $\mathrm{Y}-\mathrm{K}$ & & & 1 & & & & & & & 2 & & 3 & & \\
\hline 14 & & & & & & & & & & & & & & & \\
\hline & 1.Tercih & 1 & 5 & 2 & 2 & & 2 & & 2 & & 2 & 1 & & & \\
\hline & say1s1 & 3 & 15 & 3 & 3 & & 6 & & 6 & & 6 & 3 & & & \\
\hline & 2. Tercih & & 4 & 1 & 1 & & 5 & & 2 & 1 & & & & & \\
\hline & sayısı & & 8 & 2 & 2 & & 10 & & 4 & & & & & & \\
\hline & 3. Tercih & & & & 7 & & 1 & & & & 3 & 1 & 1 & & \\
\hline & sayısı & & & & 7 & & 1 & & & & 3 & 1 & 1 & & \\
\hline & Toplam & 3 & 23 & 5 & 12 & & 18 & & 10 & 2 & 9 & 4 & 1 & & \\
\hline & Puan & & & & & & & & & & & & & & \\
\hline
\end{tabular}


Tablo 2' deki sonuçlar değerlendirilirken 1 . tercihler 3 ile, t. tercihler 2 ile ve 3. tercihler de 1 ile çarpılarak toplam puan hanesine yazılmış ve öğrencilerin ilişkilerini gösteren sosyogram sonuçları Şekil 1'de incelenmiştir.
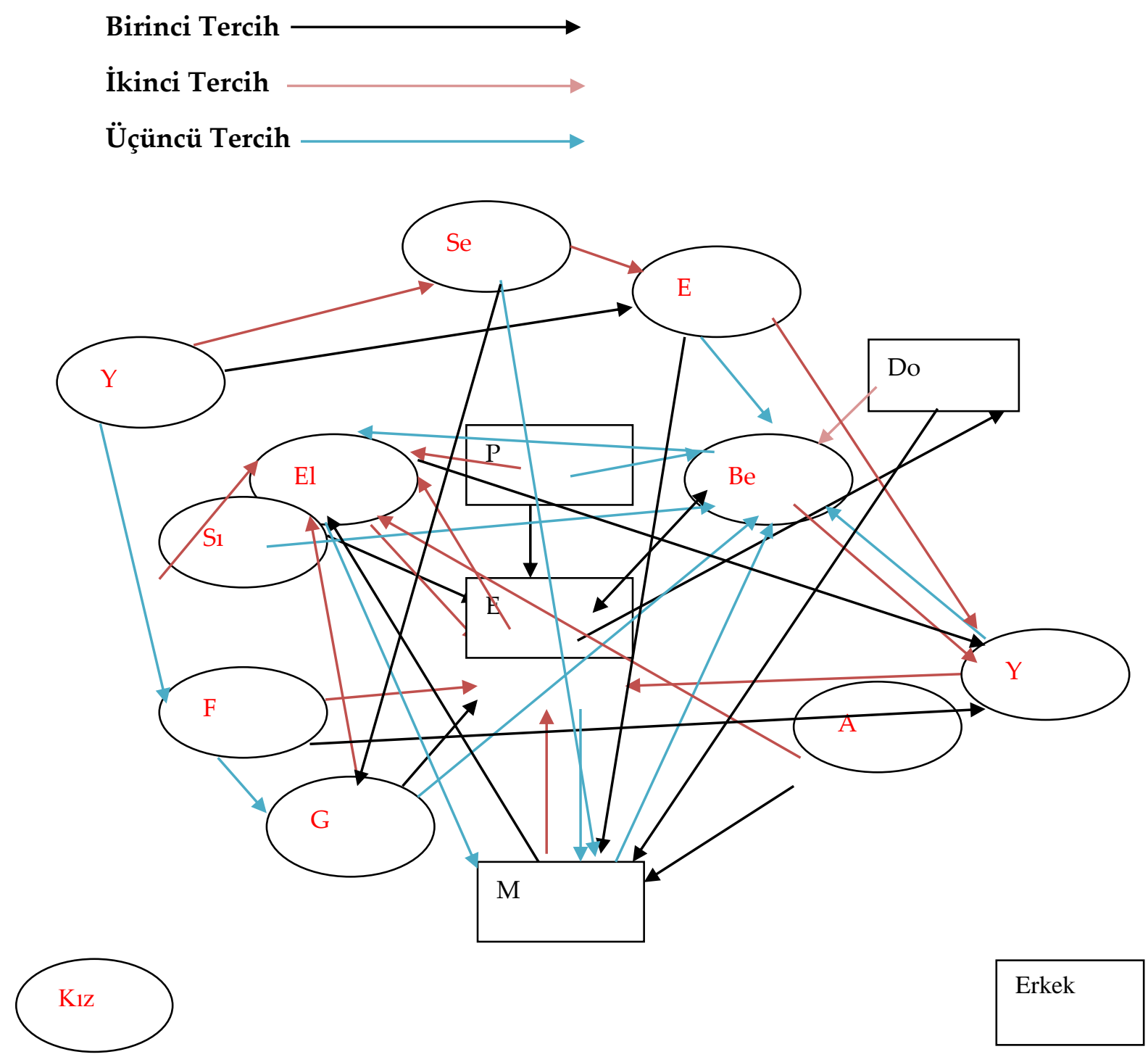

Şekil 1. Sosyogram sonuçları

Şekil 1'de sosyogram sonuçları incelendiğinde en yüksek puanı erkeklerden 23 puanla E-E'nin kızlardan ise 17 puanla El-K'nin aldığı anlaşılmıştır. El-K (17), Be-K (12) Y-K (10) ve M-K'nin (9) aldığı puanların diğer tüm öğrencilerden yüksek olduğu tespit edilmiştir. Düşük puanlar alsalar da puan sıralamasına giren öğrenciler ise, E (5), G (4),Se, Do, (3) ve F (1) arkadaşları tarafından seçilen öğrenciler arasındadır. Bu sonuçlara göre grubun liderleri, 'E-E, Be-K, Y-K ve M-E' olmak üzere 4 öğrencidir. Sınıfta arkadaşları tarafından tercih sıralamasında yer almayan öğrenciler ise 'S1-K, A-K, Y-K' olmak üzere 3 kişidir. S1-K, E-E 2. 
sırada, Be-K'yi 3. sırada ve E-K'yi 1. sırada göstermesine rağmen, hiçbir arkadaşı tarafından seçilmemiştir. İncelendiğinde seçimlerin genellikle tek yönlü olduğu görülmektedir. Örneğin G-K, 'A-K ve S1-K, El-K'i' 2. sirada göstermelerine rağmen, El-K, 2. sirada E-E'yi, 1. sirada YK ve 3. Sırada M-E’in isimlerini söylemiştir. Karşılıklı seçimlere bakıldığında ise, E-E ise, kendisini 1. sırada seçen Be-K'yi, 1. sırada seçmiştir. Ya-K, Be-K'yi 3. sırada seçerken, Be-K da Y-K'u 2. sırada seçmiştir. Sı-K, P-E, Be-K, G-K, E-E’yi 1. sırada seçen öğrencilerdir.

Öğrencilerin arkadaşlarıyla ilişkilerini daha net olarak görebilmek için, 3A sınıfındaki öğrencilere "Kimdir Bu" tekniği uygulanarak, sınıftaki arkadaşlarının belirgin özelliklerini tanımlamaları istenmiştir. Sonuçlar incelendiğinde "sınıfta en çok konuşan, herkesin sözünü kesen" öğrenciler yanında "sırasında daima sessizce oturan kimseyle ilgilenmeyen, hiç kimse tarafından dikkate alınmayan aranmayan" öğrencilerin de olduğu tespit edilmiştir. Araştırmacı ders etkinlikleri sırasında öğrenci davranışlarını gözlemlediğinde ise, 3A sınıfı öğrencilerinin bazılarında "iletişimi başlatmakta sorunlar" kimi zaman da iletişimi sürdürmekte sorunlar" olduğunu ve kimi zaman da "ders etkinliklerine katılmada ilgisizlik" davranışları gösteren öğrencilerin olduğunu gözlemlemiştir. Araştırmacının elde ettiği tüm sonuçlar sınıf öğretmeniyle paylaşılmış ve öğretmenin son değerlendirmelerini alınmıştır. Sınıf öğretmeniyle yapılan görüşmeler sırasında sınıf öğretmeni bazı öğrencilerin iletişim sorunlarının olduğu belirtmiş ve Türkçe dersinde "dinleme, konuşma, okuma, yazma" etkinliklerinin verimli bir şekilde gerçekleştirilemediği anlaşılmıştır. Elde edilen sonuçlar sınıf öğretmeniyle birlikte değerlendirildikten sonra, 3A sınıfında Türkçe ders saatlerinde öğrencilerin derse katılımlarını sağlayacak çocuk edebiyatı türlerini içine alan etkinliklerin yapılmasına karar verilmiştir.

3A sınıfında uygulanacak ders programının hazırlanması için ise, sınıf öğretmenliği ana bilim dalında 2. sınıfta öğrenimlerine devam eden öğretmen adaylarıyla görüşme yapılarak, çocuk edebiyatı etkinlikleri konulu çalışmanın kapsamı anlatılmıştır. Araştırmaya gönüllü olarak katılmak isteyen öğretmen adaylarına çalışmanın kapsamı ve uygulamayı gerçekleştirecekleri sınıf ve sınıf öğretmeni hakkında bilgiler sunulmuştur.

Okulda yürütülecek çocuk edebiyatı etkinliklerine geçilmeden önce ise çocuk edebiyatı dersini alan öğretmen adaylarına çocuk edebiyatının hedefleri, çocuk edebiyatı türleri ile her bir türe uygun olarak ne tür etkinlikler geliştirebilecekleri konusunda eğitim verilmiştir. 12 hafta süreyle uygulamaya katılacak öğretmen adaylarına yürütülecek etkinlikleri tasarlarken nelere dikkat etmeleri gerektiği konusunda rehberlik edilirken, 
öğretmen adayları da görev alacakları etkinlikler için "ne tür yöntem ve materyal kullanacakları" konusunda hazırlıklara başlamıştır. Öğretmen adayları uygulamayı gerçekleştirecekleri sınıfta gözlem çalışmaları yaptıktan sonra, uygulama konularını seçmiştir. Öğretmen adayları öğretim elemanı rehberliğinde gerekli araştırmaları da yaparak, fabl, masal, efsane, destan, öykü, anı, gezi yazısı, şiir, bilimsel buluş ve doğa olaylarını anlatan eserler, çocuk gazeteleri ve dergileri konulu etkinlik tasarlamıştır. Bu süreçte öğretmen adaylarına amaçlara uygun yöntem ve teknik seçimi, görsel, işitsel öğretmen yapımı materyaller geliştirilmesi, amaçlar yönünden sürecin değerlendirilmesi konularında bilgilendirmeler yapılırken, uygulamanın her adımda sürekli olarak dönütler verilmiştir. Uygulama öncesi öğretmen adayları, hazırladıkları planlar ile geliştirdikleri materyalleri çocuk edebiyatı dersinde sunmuş; ders öğretim üyesi ve sınıftaki diğer arkadaşlarının geliştirdikleri öneriler doğrultusunda ders planlarında (amaç, yöntem, içerik ve değerlendirme vs.) gerekli düzeltmeleri yapmıştır. Her bir uygulamanın sonrasında da sınıf öğretmeniyle görüşüp, uygulamayı değerlendiren ve grup arkadaşlarıyla birlikte gözlem sonuçlarını rapor eden öğretmen adayları, uygulama sonuçlarını çocuk edebiyatı dersinde aktarırken "Mikro Öğretim Tekniği“ uygulanmış, gruplar halinde uygulamaya katılan adaylara ders öğretim elemanı ve sınıftaki diğer öğretmen adayları dönütler vermiştir.

Öğretmen adayları çocuk edebiyatı türlerini tanıtmak amacıyla hazırladıkları etkinlikler için 1.-10. haftalar arası fabl, masal, efsane, destan, öykü, anı, gezi yazısı, şiir, bilimsel buluş ve doğa olaylarını anlatan eserlerden uygun örnekler seçerek 3A sınıfında uygulamıştır. 11. ve 12. haftada ise çocukların okumaya olan ilgilerini artırabilmek için "Sınıf Gazetesi ve Dergisi Hazırlama Etkinliği“" gerçekleştirmiştir. 12 haftanın bitiminde öğretmen adayları deneyimlerini ve gözlem sonuçlarını çocuk edebiyatı dersinde sunulduktan sonra, uygulamaya katılan öğretmen adayları ve uygulamada öğrencilere rehberlik eden sınıf öğretmeni ile görüşmeler gerçekleştirilirken, sonuç değerlendirmeleri yapılmıştır. Uygulamanın kısa ve uzun vadede etkisi değerlendirmek üzere ise 2016-2017 ders yılı başında ve sonunda olmak üzere sınıf öğretmeniyle 2 kez daha görüşme yapılarak, uygulamaya yönelik son değerlendirmelerini yapması istenmiştir. 


\section{Araştırmactnın Rolü}

Çocuk edebiyatı dersi veren öğretim elemanının rehberliğinde Muğla ili merkez ilçesine bağlı bir ilkokulda öğretmen adaylarıyla birlikte gerçekleştirilen uygulamalı çocuk edebiyatı etkinlikleri çalışması, öğrencilerin iletişim becerilerini geliştirmeyi amaçlayan bir sınıf öğretmeninin gözetiminde Türkçe dersinde yürütülmüştür. Ders öğretim elemanının rehberliğinde hazırlanıp, sınıf öğretmeninin gözetiminde uygulanan etkinlikler 12 hafta sürecek şekilde planlanmış ve 14 öğrenciden oluşan (4'ü erkek ve 10'u kız) 3A sınıfında çalışmaya gönüllü olarak katılan öğretmen adayları tarafından Türkçe dersinde uygulanmıştır. Araştırmacı etkinliklerin uygulanacağı sınıfı tanıyabilmek için sınıf ortamında gözlemler yapıp, sınıf öğretmeniyle görüşmeler de yaptıktan sonra, edindiği bilgileri öğretmen adayları ile paylaşmış ve 12 hafta süresince uygulanan etkinlikler süresince öğretmen adaylarına rehberlik etmiştir.

Nitel araştırmalarda araştırmacılarda araştırmaya başlamadan önce araştırmacıların kişisel görüş ve önyargılardan uzak bir tutum takınarak, yönlendirme yapmaksızın katılımcı görüşlerini doğru bir şekilde aktarmaları gerektiğinden (Creswell, 2014; Patton, 2014; Yin, 2011) araştırmacı, araştırma süreci boyunca kişisel görüş ve önyargılardan uzak bir tutum takınmış, katılımcıların görüşlerini ve değer yargılarını objektif bir tutumla değerlendirmeye çalışmıştır. Uygulamalar tamamlandığında süreçte neler yapıldığını ve öğretmen adaylarının ne tür etkinlikler hazırladıklarını değerlendirmiştir. Sonuç değerlendirmeleri temasında da gerçekleştirilen etkinliklere yönelik katılımcıların görüşlerini incelemiştir. Bulguları temalar halinde betimsel bir anlatım ile sunmaya, katılımcı ifadelerini gerçekçi bir şekilde yansıtmaya özen göstermiştir. Çalışmada uygulama okulu adı, görüşleri alınan öğretmen adayı ve sınıf öğretmeninin kimlik bilgileri gizli tutulacağı sözü verildiğinden alıntılarda katılımcı ifadeleri aktarılırken, aday öğretmenler ve sınıf öğretmeni için kod isimleri kullanılmıştır. 2A şubesinden uygulamaya katılan öğretmen adayları 1'den 26'ya; 2B şubesinden uygulamaya öğretmen adayları $27^{\prime}$ den $47^{\prime}$ ye kadar sıralanmıştır. Kod isimlerde erkekler için $E$ ve kadınlar için $K$ harfi kullanıldığından 'ÖA1- $K$ ' örneğinde, 'Ö $A 1^{\prime} 2 \mathrm{~A}$ şubesinden birinci sırada çalışmaya katılan kadın öğretmen adayını simgelemektedir. Sınıf öğretmeni için kullanılan 'Ö-K-20-53' kod ismindeki harf ve rakamlar ise sırasıyla 'sınıf öğretmenini, cinsiyetini, meslekteki kıdemini ve yaşını' ifade etmektedir. 


\section{Araştırmada Geçerlik ve Güvenirlik}

Araştırma verileri analiz edilirken "inandırıcılık, tutarlık, aktarılabilirlik, teyit edilebilirlik“ ölçütleri dikkate alınmıştır. İnandırıcılığı artırabilmek için, çalışma grubunda yer alan katılımcıların görüşleri ayrıntılı olarak sunulurken, betimlemeler yapılmasına (Johnson \& Chiristensen, 2014) özen gösterilmiştir. Aktarılabilirlik ölçütünü sağlayabilmek için (Lincoln \& Guba, 1985) doğrudan alıntılara yer verilmiştir. Bulguların sunulurken güvenirliği artırmak için veriler temalar ve kodlar halinde sunulmuştur. Doğrudan alıntılar yapılırken sınıf öğretmeni, aday öğretmenlerin görüşlerinin doğru bir şekilde aktarılmasına (Creswell, 2014; Patton, 2014) özen gösterilirken alıntılar yapılan kısımlara 'ÖA1-E.' ve 'Ö-K20-53.' örneğinde olduğu gibi katılımcıları simgeleyen kodlar eklenmiştir. Tutarlılık ölçütünü gerçekleştirmek için veriler sürekli karşılaştırılmış, bulgular ortaya konulurken yorum ya da genelleme yapılmamasına özen gösterilmiştir. Teyit edilebilirlik ölçütünü sağlamak için araştırma verileri araştırmacı tarafından saklanmıştır. Ayrıca araştırmada doküman incelemesi, gözlem ve görüşme gibi yöntemler bir arada kullanılarak (Creswell, 2014) geçerlik ölçütü sağlanmaya çalışılmıştır.

\section{Verilerin Analizi}

Çocuk edebiyatı kapsamında öğretmen adaylarının yaptıkları çalışmaların etkililiğini ortaya koyabilmek için öncelikle ders öğretim elemanı tarafından sürece yönelik değerlendirmeler yapılmıştır. Bu aşamada öğretmen adaylarının tasarlayıp, uyguladıkları etkinlikler doküman incelemesi yöntemiyle değerlendirilmiştir. Sonuç değerlendirmeleri için ise öğretmen adayları ve sınıf öğretmeninin görüşlerine başvurulmuş; bu kısımda 'içerik analizi ve betimsel analiz tekniği' kullanılarak veriler analiz edilmiştir.

\section{Bulgular}

Uygulamanın niteliğinin değerlendirildiği bu başlıkta araştırma bulguları; “Çocuk Edebiyatı Etkinliklerinin Değerlendirilmesi (Süreç)" ve "Uygulanan Etkinliklerin Etkililiğinin Değerlendirilmesine İlişkin Görüşler (Sonuç) “ olmak üzere iki başlık altında incelenmiştir (Şekil. 2).

Çocuk Edebiyatı Etkinliklerinin Değerlendirilmesi (Süreç)

Uygulanan Etkinliklerinin Etkililiğine Yönelik Görüşler (Sonuç)

Şekil 2. Çocuk edebiyatı ders etkinliklerine yönelik değerlendirmeler 


\section{Çocuk Edebiyatı Etkinliklerinin Değerlendirilmesi (Süreç)}

$\mathrm{Bu}$ başlıkta çocuk edebiyatı dersi kapsamında öğretmen adaylarının hazırlayıp, uyguladıkları ders etkinlikleri ders öğretim elemanı tarafından incelenerek süreç değerlendirmesi yapılmıştır. Çocuk edebiyatı etkinliklerinde görev alacak öğretmen adayları belirlenirken 3-4 kişilik gruplar oluşturulmuş ve öğretmen adayları 2A ve $2 \mathrm{~B}$ şubesinden ayrı ayrı olmak ders öğretim elemanının rehberliğinde 12 hafta süresince uygulanacak 24 uygulama planı hazırlamıştır. Uygulama planları çocuk edebiyatı dersinde 2A ve 2B şubesinde ayrı ayrı incelenip gerekli düzeltmeler de yapıldıktan sonra 12 haftalık süre boyunca Muğla merkezine bağlı bir ilkokulda 3A sınıfında sınıf öğretiminin gözetiminde Türkçe dersinde öğretmen adayları tarafından uygulamıştır. Her bir uygulama sonrası ise deneyimlerini ve gözlem sonuçlarını rapor eden öğretmen adayları, sunumları nasıl gerçekleştirdiklerini ne tür deneyimler elde ettiklerini sınıf ortamında paylaşırken "Mikro Öğretim Tekniği“ uygulanmış ve sürece yönelik değerlendirmeler yapılmıştır.

Süreç değerlendirilmelerinde sınıf öğretmeni adaylarının ilkokul öğrencileri için 3. sınıf düzeyinde Türkçe dersi için hazırlayıp uyguladıkları çalışmaların niteliği değerlendirilirken öğretmen adaylarının çocuk edebiyatı dersinin amaçlarının ne kadar farkında oldukları belirlenmeye çalışılmıştır. Etkinlikler incelendiğinde öğretmen adaylarının "soru-cevap, gösterip-yaptırma, drama, oyun, örnek olay" gibi yöntem ve tekniklerden yararlandıkları belirlenmiştir. Öğretmen adaylarının etkinlikler sırasında öğrencilerin dikkatlerini çekebilmek ve öğrenmelerini kolaylaştırabilmek için "görsel-işitsel öğretmen yapımı materyaller" kullandıkları ve uygulamalar sırasında öğrenirken eğlenmelerini de sağlamaya çalıştıkları tespit edilmiştir. Her bir etkinlik sonrası süreci değerlendirirken "akran değerlendirme ve öz değerlendirme" tekniklerine başvurarak hedeflenen kazanımlara ulaşma derecesini kontrol etmeye özen gösterdikleri anlaşılmıştır.

Öğretmen adaylarının hazırlayıp, uyguladıkları etkinlikler genel olarak değerlendirildiğinde ise her bir etkinliğin çocuk edebiyatı dersinin amacına uygun olduğu tespit edilmiştir. Öğretmen adaylarının uyguladıkları etkinliklerde farklı yöntem ve tekniklerden yararlandıkları, uygulamalar sırasında öğrenci katılımına önem verirken hedefler ve içerikle uyumlu materyal kullandıkları, uygulama sonunda ise öğrencilerin düzeylerini değerlendirmeye yönelik çalışmalar yaptıkları anlaşılmıştır. Aşağıda öğretmen adaylarının hazırladığı iki örnek etkinlik raporu özetlenerek sunulmuştur. 
Tablo 3. Etkinlik raporu (Sınıf Öğretmenliği 2A)

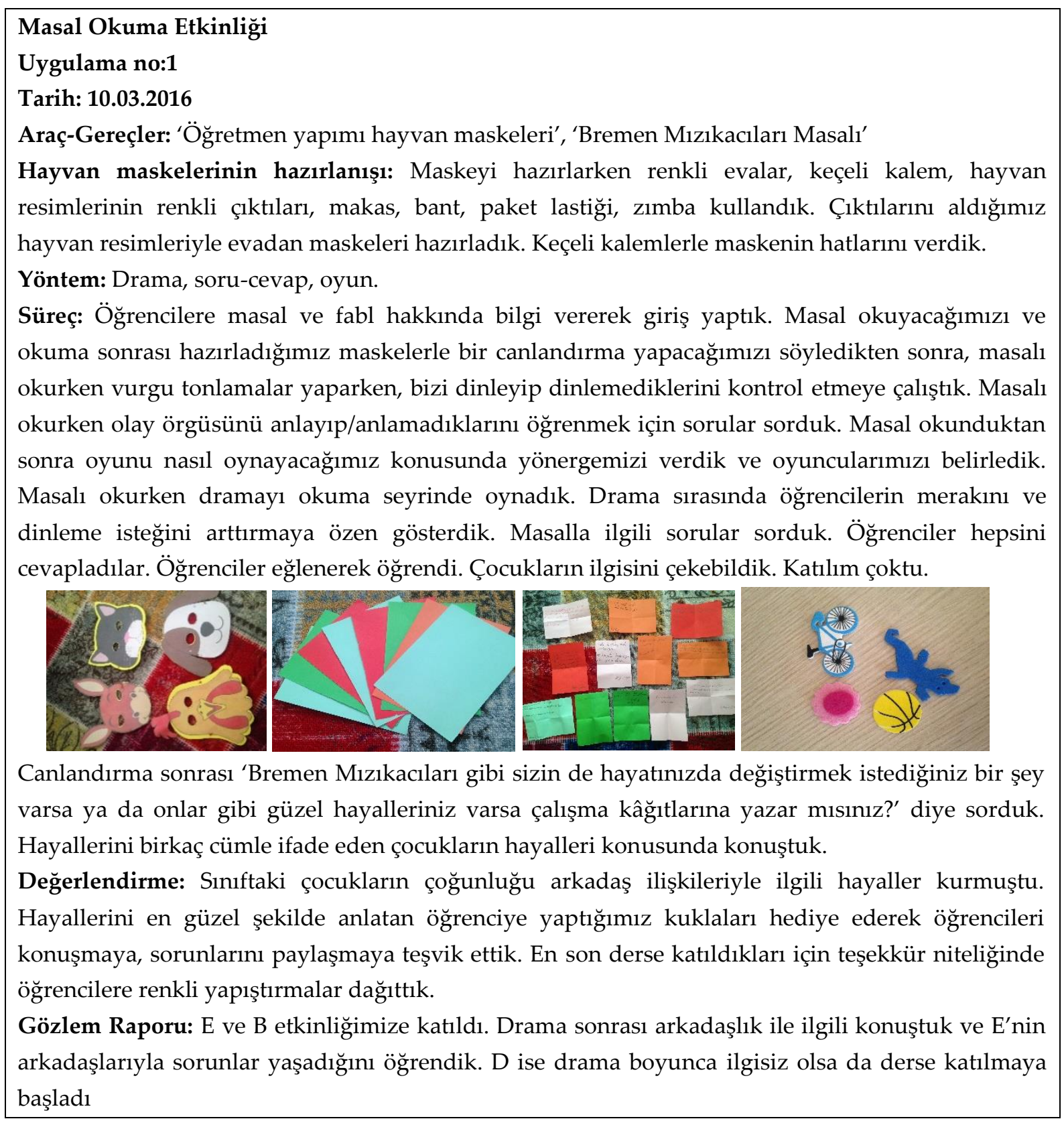

Tablo 4. Etkinlik raporu (Sınıf Öğretmenliği 2B)

\section{Tekerleme ve Sayışmaca Etkinliği \\ Uygulama no: 9}

Tarih: 20.04.2016

Araç-Gereçler: Rapunzel masalı, sayışmacalar ve tekerlemeler için öğretmen yapımı materyaller.

Öğretmen Yapımı Materyalin Hazırlanışı: Kutu, resim kartları, tekerleme kartları, tekerleme kitabı hazırlandı. Materyalin geliştirilmesinde renkli fon kartonlar, yapıştırıcı, makas, kurdele, farklı resimler, kutu, kaplık, silikon kullanıldı.

Süreç: Etkinliğe geçmeden önce daha önceden okuduğumuzu bir masalı hatırlatarak tekerleme konusunu işleyeceğimizi ve etkinlik sonrasında da oyun oynayacağımız söyledik.

Rapunzel masalının başındaki tekerlemeyi okuyarak öğrencilerin dikkatini çektik. Tekerleme 
konusundaki düşünceleri sorduktan sonra, bildikleri tekerlemeleri söylemelerini istedik. Masaldaki tekerlemenin nerede kullanıldığına örnekler vermelerini istedik. Sayışmaca ve tekerleme arasındaki farkı bulmalarını sağladıktan sonra, bildikleri sayışmacalardan örnekler vermelerini istedik. Sayışmacalar yapılırken, tekerleme etkinliğine başlamak için bir öğrenci seçtik. Belirlediğimiz öğrenci kutu içinde bulunan tekerleme kartlarından birini seçerek, sınıfa okudu. Öğrenciden tahtaya astığımız resimlerden hangisinin okuduğu tekerlemeye uygun olduğunu söylemesini istedik. Tekerlemeler okunup, resimlerle eşleştirildikçe öğrencilere ödüller (sticker şeklinde yıldızlar) verip motive etmeye çalıştık. Okumalar sırasında tekerlemelerin doğru okunmasının önemli olduğu belirttik. Tekerleme okumanın okuma ve konuşmada kolaylık sağlayacağına dikkat çektik.
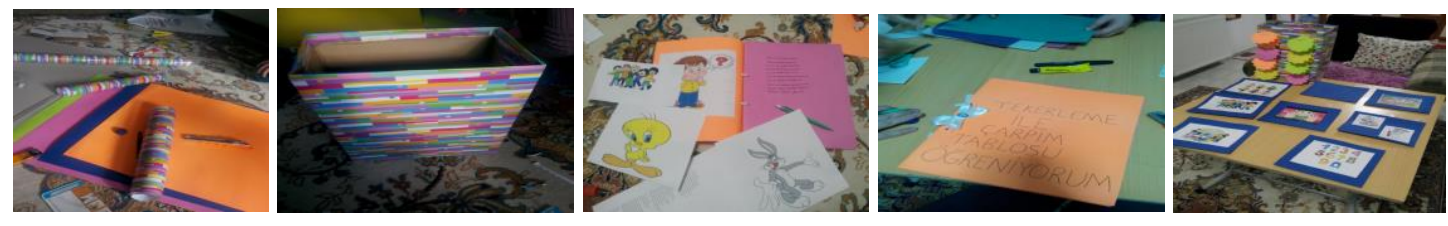

Değerlendirme: Kutu içindeki tüm tekerlemeler bittiğinde tüm sınıfın katılımını da sağlamaya çalışarak tekrar tekerlemeleri okuttuk. Hazırladığımız 'Tekerleme Kitabı'ndan başka örnekler okumalarını istedik. Okumalar bittiğinde 'Tekerleme Kartları ile Tekerleme Kitabını' sınıf kitaplığına birlikte yerleştirdik.

Gözlem: Ders esnasında etkinlik yapmada ya da fikrini söyleme konusunda aktif olan çocuklar vardı. Bunlar ' $\mathrm{P}, \mathrm{M}, \mathrm{E}$ ' idi. $\mathrm{S}$ ise derse katılmayan bir öğrenci olmasına rağmen derse katıldı. Çekingen bir kişiliği var. Aynı şekilde A'nın da etkinliklere katıldığını gözlemledik.

\section{Uygulanan Etkinliklerin Etkililiğine Yönelik Görüşler}

Sonuçların değerlendirildiği bu başlıkta çocuk edebiyatı etkinliklerinin etkililiğinin değerlendirilmesine ilişkin görüşler analiz edilirken, sınıf öğretmeninin ve öğretmen adaylarının görüşleri ayrı başlıklarda incelenmiştir. Uygulamaya katılan aday öğretmenler ile sınıf öğretmenin görüşlerine başvurularak, öğretmen adaylarının çocuk edebiyatı türlerine uygun olarak tasarlayıp uyguladıkları etkinliklerin gerek öğrencilerin iletişim becerilerini geliştirmeye ve gerekse öğrencilerin derse katılımlarını sağlamaya yönelik etkisi ortaya konulmaya çalışılmıştır.

\section{Sını Öğretmeninin Çocuk Edebiyatı Etkinliğine Yönelik Görüşleri}

Çocuk edebiyatı etkinliğiyle ilgili sınıf öğretmeninin sonuç değerlendirmelerine bakıldığında öğretmen adaylarının gerçekleştirdikleri etkinlikleri genel olarak "verimli, başarılı, yararlı" olarak değerlendirdiği tespit edilmiştir. Öğretmen adaylarının her birinin etkinliklerin sunumunu başarılı bir şekilde yerine getirdiklerini ifade eden gözlemci sınıf öğretmeni, adayların etkili ve farklı materyaller kullanmaya özen gösterdiklerini, öğrencilerin derse olan ilgilerini artırabildiklerini ve öğrencilerle iletişim kurabildiklerini belirtmiştir. Sınıf öğretmeni uygulamalar sonucunda sınıfında bulunan tüm öğrencilerin 
neredeyse tamamının çocuk edebiyatı türlerine olan ilgisinin arttığını dolayısıyla, okumaya

karşı daha istekli tutumlar geliştirdiklerini belirttiği anlaşılmıştır. Kapsayıcı bir bakış açısı

sunabilmek için öğretmen adaylarını gözlemleyen sınıf öğretmeninin görüşleri detaylı şekilde aktarılmıştır.

Ö-K-20-53.'Öğretmen adayları Türkçe dersinin etkinlik alanlarını birbirleriyle ilişkilendirerek, çocuk edebiyatı türlerine yönelik hazırladıkları etkinlikleri uyguladılar. Sunumlarını başarılı bir şekilde gerçekleştirdiler. Çalışmalarını hazırlarken çok özenli olduklarını gözlemledim. Materyal kullanımı oldukça çok iyiydi. Çocukların görsel hafizalarına hitapeden araçlar kullandılar. Kendi hazırladıkları öğretmen yapımı materyallerle çocuk edebiyatı türlerini işlerken çocukların dikkatini çekebilmeyi başardılar. Etkinlikler sırasında 'resimler, dikkat çekici kavram kartları, çalışma kă̆ıtları, üç boyutlu maketler/kavram haritaları' çocukların öğrenmesini kolaylaştırdı ve derse katılımlarını olumlu yönde etkiledi. Kullandıkları araçlar, tüm öğrencilerin sadece ilgisini çekmekle kalmayıp, öğrenmelerini de kolaylaştırdı. Öğretmen adayları somut olan konuları ele alırken, elle tutulur materyaller kullandıkları için öğrenciler 'masal, öykü, destan, efsane, şiir' gibi çocuk edebiyatı türlerini çok büyük dikkatle dinlerken derse katılım gösterdiler ve anlatılanlarn ilgiyle izlediler. Öğretmen adaylarının çocuk edebiyatı türlerini ele aldıkları etkinler sırasında öğrenme sürecini oyunlaştırmaları çok yararlı oldu... Çocuklar birebir etkinlik içinde oldukları için çok eğlenirken, öğrendiler. Ödülleri uygun şekilde kullandilar ve bu konuda çok başarılı idiler.'

'Öğretmen adayları çocuk edebiyatı kapsamında masallar, öyküler, mitler, efsaneler, destanlar, şiirler, öyküler şiirler, gezi yazıları, biyografik eserler, fen-doğa olayları gibi türlerden seçtikleri örneklerle uygulamalar yaptıkça, öğrencilerim edebiyat kapsamında farkh türler olduğunu keşfetmeye başladılar. Okul ya da sinıf kütüphanemizde 'destan, efsane, fen ve doğa olaylarını' anlatan kitaplar olmadığı için, öğrencilerim bunlar tanıma ve okuma imkânı da buldular. Diğer sınıflarla benim öğrencilerimin bu konudaki bilgi seviyesini karşılaştırdığımda, öğrencilerimin çocuk edebiyatı türleri konusunda bilgi sahibi oldukların söyleyebilirim. Ders aralarında öğretmenlerle konuştuğumda bu farkı ayırt edebiliyorum...'

'Öğretmen adayları öğrencileri derse katmak için çok büyük çaba gösterdiler, iletişim dilleri oldukça etkiliydi. En sessiz öğrenciyi, derse katabilmek için ellerinden geleni yaptılar. Etkinlikleri uygularken, öğrencilerle göz teması kurmaya, onları dikkatle dinlemeye özen gösterdiler. Öğrenciyi derse katabilmek için, kimi zaman öğrencinin yanına oturup, dersi beraber izlerken, motive edici bir dil kullandılar. Çocuklarla ders aralarında bile bağlantılarını koparmadılar. Çocuklarla birlikte olmaktan keyif aldılar. Bu uygulamaları izlerken tüm adayların mesleğe hazır olduklarım gözlemledim. Etkinlikler sırasında çocukları ö̆grenmenin merkezine yerleştirme konusunda çok başarlliydılar...'

'Çocuk edebiyatı türlerinden örnekler sunarken de Türkçe dersinin 'dinleme okuma, anlama ve yazma alanların görsel okuma ve görsel sunu alanıyla ilgili bağlantılar kurdular ve bu yararlı oldu. Öğretmen adayları ekinlikler sırasında öğrencilerin kelime dağarcığını zenginleştirecek uygulamalara yer verdiler. Yeni kelimeleri kullanmaya çalıştılar ve kullandırdılar... Ezbere değil, düşünmeye yorum yapmaya yönelik uygulamalar yaptılar. Yaratıcı düşünmeye özendirmek amaçl etkinlikler sırasında, çocuklarm hayallerini zorladılar. Destan, fabl, hikâye, masal gibi çocuk edebiyatı türlerine yönelik çalş̧malar yaparken çocukların günlük hayattan çıkarımlar yapmalarım să̆ladılar. Çocuk edebiyatının farklı türlerinden örnekler sunarken çocuklara olumlu davranışlar kazandırmaya çalıştılar...'

'Bir dönem boyunca yapılan bu etkinlikler sayesinde öğrencilerimin kendilerini ifade etme becerilerinin geliştiğini gözlemledim. Öğrencilerim duygularını, düşüncelerini, hayallerini daha rahat ifade etmeye başladılar. Hiç konuşmayan öğrencinin sinıfta varlığını diğer çocuklara hissettirdiler. Aaa öğretmenim $S$ de konuştu şeklinde tepkiler verdiler öğrencilerim. Çünkü S hiç konuşmazdı. Bazı öğrenciler dikkat çekmek amacıyla katılmazlar ya onlara dahi 
ulaştılar. Çocuklara güven duygusu aşıladılar. Kelime hazinelerine yeni kelimeler katıp, kullanmalarını sağladılar. Bence bu etkinlikler öğretmen adayları açısından da yararlı oldu. Eğitim fakültelerinde öğretmen adaylarının sürekli uygulamanın içinde olacakları bu tür etkinlikler yapmalarının çok yararlı olduğunu dü̧̈ünüyorum. Öğretmen adayları açısından değgerlendirdiğimde, kullandıkları materyallerle çocuk edebiyatı türlerini tanıtmada başarılı oldular. Çocukların davranışlarını değiştirmeyi öğrendiler. Bu uygulamalar sırasında öğrenciler gibi öğretmen adaylarının da mutlu olduğunu gözlemledim. Bu tür bir çalısma içinde olmaktan da ben de ayrica keyif aldım ve mutlu oldum....'

\section{Öğretmen Adaylarının Çocuk Edebiyatı Etkinliğine Yönelik Görüşleri}

Bu başlıkta öğretmen adaylarının çocuk edebiyatı etkinliğine yönelik görüşleri ‘öğrenci açısından ve öğretmen adayları açısından değerlendirmeler' olmak üzere iki alt tema halinde analiz edilmiştir (Tablo 5.)

Tablo 5. Öğretmen adaylarının çocuk edebiyatı etkinliğine yönelik görüşleri

\begin{tabular}{|c|c|c|c|}
\hline & Kodlar & Katılımcılar & Frekans (f) \\
\hline \multirow[t]{10}{*}{$\overline{1}$} & Öğrenciler açısından & & \\
\hline & Yararlı & $\begin{array}{l}\text { ÖA1, ÖA2, ÖA3, ÖA5, ÖA6, ÖA7, ÖA8, ÖA9, ÖA10, ÖA11, ÖA12, } \\
\text { ÖA13, ÖA14, ÖA15 ÖA14, ÖA16, ÖA17, ÖA18, ÖA19, ÖA20, } \\
\text { ÖA21, ÖA22, ÖA23, ÖA24, ÖA25, ÖA26, ÖA27, ÖA28, ÖA29, } \\
\text { ÖA30, ÖA31, ÖA32, ÖA33, ÖA34, ÖA35, ÖA36, ÖA37, ÖA38, } \\
\text { ÖA39, ÖA40, ÖA41, ÖA42, ÖA43, ÖA44, ÖA45, ÖA46, ÖA47 }\end{array}$ & 47 \\
\hline & Etkili & $\begin{array}{l}\text { ÖA1, ÖA2, ÖA5, ÖA6 ÖA7, ÖA8, ÖA9, ÖA11, ÖA14, ÖA18, } \\
\text { ÖA21, ÖA22, ÖA26, ÖA30, ÖA38, ÖA40, ÖA41 }\end{array}$ & 17 \\
\hline & Nitelikli & ÖA1, ÖA2, ÖA6, ÖA30, ÖA32, ÖA38, ÖA40 & 7 \\
\hline & $\begin{array}{l}\text { Öğrenciler bilgi sahibi } \\
\text { oldular. }\end{array}$ & $\begin{array}{l}\text { ÖA1, ÖA2, ÖA5, ÖA6, ÖA7, ÖA8, ÖA9, ÖA10, ÖA15, ÖA31, } \\
\text { ÖA34, ÖA37, ÖA38, ÖA39, ÖA41, ÖA42, ÖA43, ÖA44, ÖA46 }\end{array}$ & 19 \\
\hline & $\begin{array}{l}\text { Öğrenciler etkinliklere ilgi } \\
\text { gösterdiler. }\end{array}$ & $\begin{array}{l}\text { ÖA1, ÖA2, ÖA3, ÖA4, ÖA5, ÖA7, ÖA8, ÖA10, ÖA11, ÖA12, } \\
\text { ÖA13, ÖA14, ÖA15, ÖA16, ÖA17, ÖA20, ÖA21, ÖA23, ÖA24, } \\
\text { ÖA27, ÖA29, ÖA31, ÖA33, ÖA34, ÖA35, ÖA36, ÖA38, ÖA39, } \\
\text { ÖA40, ÖA41, ÖA42, ÖA43, ÖA44, ÖA45, ÖA46, ÖA47 }\end{array}$ & 36 \\
\hline & $\begin{array}{l}\text { Öğrenciler eğlendiler/mutlu } \\
\text { oldular. }\end{array}$ & $\begin{array}{l}\text { ÖA1, ÖA2, ÖA6, ÖA7, ÖA8, ÖA11, ÖA12, ÖA14, ÖA15, ÖA19, } \\
\text { ÖA20, ÖA23, ÖA26, ÖA28, ÖA29, ÖA31, ÖA35, ÖA40, ÖA41, } \\
\text { ÖA44, ÖA47 }\end{array}$ & 21 \\
\hline & $\begin{array}{l}\text { Öğrenciler kendilerini ifade } \\
\text { edebildiler. }\end{array}$ & $\begin{array}{l}\text { ÖA2, ÖA4, ÖA7, ÖA8, ÖA9, ÖA11, ÖA12, ÖA14, ÖA15, ÖA17, } \\
\text { ÖA18, ÖA32, ÖA34, ÖA40 }\end{array}$ & 14 \\
\hline & $\begin{array}{l}\text { Öğrenciler derse aktif } \\
\text { katılım gösterdiler. }\end{array}$ & $\begin{array}{l}\text { ÖA2, ÖA3, ÖA4, ÖA5, ÖA6, ÖA7, ÖA8, ÖA9, ÖA11, ÖA12, ÖA13, } \\
\text { ÖA14, ÖA15, ÖA16, ÖA17, ÖA18, ÖA19, ÖA20, ÖA21, ÖA28, } \\
\text { ÖA29, ÖA31, ÖA32, ÖA33, ÖA34, ÖA35, ÖA36, ÖA37, ÖA38, } \\
\text { ÖA40, ÖA41, ÖA45 }\end{array}$ & 32 \\
\hline & $\begin{array}{l}\text { Akılda kalıcı bir çalışma } \\
\text { oldu. }\end{array}$ & ÖA10, ÖA21 & \\
\hline \multirow[t]{5}{*}{2} & Öğretmen adayları açısından & & \\
\hline & Keyifli & $\begin{array}{l}\text { ÖA1, ÖA2, ÖA5, ÖA6, ÖA7, ÖA15, ÖA17, ÖA34, ÖA40, ÖA41, } \\
\text { ÖA45 }\end{array}$ & 11 \\
\hline & Eğlenceli & $\begin{array}{l}\text { ÖA1, ÖA2, ÖA5, ÖA6, ÖA6, ÖA7, ÖA10, ÖA12, ÖA13, ÖA15, } \\
\text { ÖA20, ÖA41, ÖA47 }\end{array}$ & 13 \\
\hline & Yararlı & $\begin{array}{l}\text { ÖA1, ÖA2, ÖA3, ÖA4, ÖA6, ÖA7, ÖA8, ÖA9, ÖA10, ÖA11, ÖA14, } \\
\text { ÖA15, ÖA17, ÖA18, ÖA20, ÖA21, ÖA30, ÖA34, ÖA35, ÖA36, } \\
\text { ÖA37, ÖA38, ÖA40, ÖA41, ÖA42, ÖA45 }\end{array}$ & 26 \\
\hline & Öğrencileri güdüleyebildik. & ÖA1, ÖA2, ÖA5, ÖA7, ÖA8, ÖA9, ÖA11, ÖA15, ÖA16, ÖA20, & 13 \\
\hline
\end{tabular}




\begin{tabular}{|c|c|c|}
\hline $\begin{array}{l}\text { Uygulamalar } \\
\text { eğlendik. }\end{array}$ & $\begin{array}{l}\text { ÖA34, ÖA38, ÖA41 } \\
\text { ÖA1, ÖA2, ÖA7, ÖA17, ÖA21, ÖA23, ÖA41 }\end{array}$ & 7 \\
\hline Mutlu hissettim. & $\begin{array}{l}\text { ÖA1, ÖA2, ÖA4, ÖA6, ÖA14, ÖA15, ÖA18, ÖA20, ÖA21, ÖA22, } \\
\text { ÖA23, ÖA28, ÖA29, ÖA30, ÖA32, ÖA33, ÖA34, ÖA35, ÖA36, } \\
\text { ÖA37, ÖA38, ÖA39, ÖA40, ÖA41, ÖA42, ÖA43, ÖA44, ÖA47 }\end{array}$ & 28 \\
\hline $\begin{array}{l}\text { Öğrenciler hakkında fikir } \\
\text { edindim/öğretmenlik } \\
\text { deneyimi kazandım. }\end{array}$ & $\begin{array}{l}\text { ÖA9, ÖA11, ÖA12, ÖA13, ÖA14, ÖA15, ÖA16, ÖA17, ÖA18, } \\
\text { ÖA19, ÖA20, ÖA21,ÖA22, ÖA23, ÖA24, ÖA26, ÖA27, ÖA28, } \\
\text { ÖA29, ÖA30, ÖA31, ÖA32, ÖA34, ÖA38, ÖA40, ÖA44, ÖA45, } \\
\text { ÖA46, ÖA47 }\end{array}$ & 29 \\
\hline
\end{tabular}

Tablo 5'te çocuk edebiyatı ders etkinliklerinin etkililiğine yönelik görüşleri incelendiğinde, öğretmen adaylarının çalışmayı öğrenci açısından genel olarak “etkili, yararlı ve nitelikli" olarak değerlendirdikleri sonucuna ulaşılmıştır. Öğretmen adayları açısından çalışmayı nasıl değerlendirdiklerine bakıldığında ise öğretmen adaylarının uygulamaları "keyifli, eğlenceli ve yararlı buldukları", etkinlikler sırasında öğrencileri bilgilendirirken, eğlendirebildiklerini, güdüleyebildiklerini belirttikleri anlaşılmıştır. Ayrıca etkinlikler sırasında hem kendilerinin ve sınıftaki öğrencilerin mutlu olduğunu hissettiklerini ifade ettikleri tespit edilmiştir. Aşağıda sınıf öğretmeni adaylarının örnek ifadeleri iki ayrı başlık altında aktarılmıştır.

\section{Öğrenci açısından}

ÖA1-E. 'Etkinlik için grup olarak fabl hazırladik. Derse girişte, fabl ne demek, nasıl yazılır? şeklinde sorular sorarak öğrencilerin ön bilgilerini ortaya çıkarmaya çalışık. Hazırladığımız materyal eşliğinde bir fabl örneği okuduktan sonra, öğrencilerin bildikleri fabl örnekleri varsa anlatmaların istedik. Bu çalışma ile öğrencilerin düşüncelerini rahatça ifade etmelerini sağladık. Yaptığımız çalışma ile çocukların ilgi, dikkat ve algı becerilerini harekete geçirmiş olduk.

ÖA6-E. 'Gezi yazıların konu alan bir etkinlik hazırladık. Etkinlik sırasında öğrencilerle iletişim kurabildik. Kullandığımız materyal ve çocuklara olan yaklaşımımızdan çocuklar etkilendiler. Gezi yazısı konusunda bilgiler edindiler.'

ÖA7-K.'Çocuklar gayet aktif olarak derse katıllm gösterdiler. Sinffa girer girmez sorular sormaya başladılar. Etkinlikler sirasinda da gayet iyi dinlediler. Sinıfin neredeyse hepsi etkinliklere katıldı. Öğrenciler eğlendiler. Öğrenmesini sağlarken, eğlenmesini de sağlamış olduk. Tekerlemeler ve sayışmacalar çocukların çok hoşuna gitti. Kullandığımız materyaller öğrencilerin çok ilgisini çekti. Bence yaptığımız etkinlik öğreticiydi.'

ÖA11-K. 'Çocuklar etkinlikler sirasında hem bizimle hem de arkadaşlarıla iletişim kurabildiler. Derste oldukça aktiflerdi. Etkinler sırasında kullandığımız materyal ilgilerini çekti ve konuyu öğrenmelerini sağladı. Aktif öğrenme yoluyla çocukların öğrenmelerini kolaylaştırmaya çalıştık. Öğrencilerin iletişim becerilerini geliştirmek için hazırladığımız çalışmalar sırasında tekerlemelerden yararlandık. Etkinlikler sırasında çocukların fikirlerini, duyguların dikkate alarak onlarla iletişim kurmaya çalıştım. Materyal kullanınca çocukların derse isteklerinin arttığıı ve daha dikkatli bir şekilde katılım gösterip, motive oldukların gözlemledim.' 
ÖA15-K. 'Öğrencilerin dikkatlerini çekmede başarılıydık. Öğrencilerden anlattığımız konuyla ilgili dönütler alabildik. Öğrencilerle vakit geçirmek, onlara bir şeyler öğretebilmek güzeldi. Bizi sevip, tekrar gelin demeleri çok güzel bir duyguydu.'

ÖA20-K. 'Kullandı̆̆ım materyal çocukların çok dikkatini çekti. Konuyu sunarken çocuğun seviyesine inmeye çalışık. Etkinlik sırasında resimlerden, bulmacalardan yararlandık. Hazırladığımız dönme dolap materyali çocukların çok ilgisini çekti. Sorduğumuz sorulara cevap verme konusunda çok istekli olmalarını să̆ladı. Özellikle dikkat çekme aşamasında ve konuların pekiştirildiği aşamalarda kullandığımız materyaller onları çok motive etti.'

ÖA21-K. 'Hazırladığımız çalışmayı çoklu zekânın tüm alanlarının kullanıldığı bir etkinlik şekilde uyguladık. Öğrencilerimize eğlenerek, öğrenme firsatları tanımış olduk. Derse 'animik fare' şarkısıyla girmemiz çocukların dikkatlerini çekti. Aynı zamanda yaptığımız etkinliklere girişimizi kolaylaştırdı. Öğrenciler etkinliklere katılırken, ilgiyle dinlediler. Sunum sırasında içten ve samimi bir dil kullanmaya özen gösterdik ve öğrenci sorularım cevaplarken, sorduğumuz sorularla derse katılımlarını sağlamaya çalıştık..'

ÖA34-K. 'Etkinlik hazırlarken şiir türlerini ele aldık. Öğrencilere şiirler okurken, şiir türleriyle (epik, lirik, dramatik gibi) ilgili bilgiler verdik. Öğrenciler şiir konusunda sorulan sorulara doğru cevaplar verdiler. Etkinlik ilgilerini çekti. Uygulamalar sırasında şiirlerin nasıl okunması gerektiğine de dikkat çekerek farklı şiir türlerinin okunuşlarına örnekler verdik. Etkinlikler sırasında resimler, balonlar, renkli not kâ̆ğıtları kullandik. Etkinlik bence çok başarll oldu. Öğrencilerin olumlu tepkilerini gördüğüm için böyle düşünüyorum. Çalışma sırasında çocuklara söz hakkı verdik, materyaller öğrencilerin ilgisini çekti. Öğrencilerin derse olan ilgisi beni de çok mutlu etti.'

ÖA38-E. 'Konumuz destandı. Renkli kartonlardan maketler hazırladık, konuyu öğretmek için, ayrıca öğrencilere soracă̆ımız sorular için çalışma yaprağ $ı$ çoğalttık. Destan kartlarımızı da kullanarak öğrencilerin bilgi edinmesini sağlamaya çalıştık. Etkili bir sunum gerçekleştirdik. Materyal öğrencilerin hoşuna gitti, onlara olan yaklaşımımız da ayrıca hoşlarma gitti ve motive etti. Çocuklarm destanla ilgili hiçbir ön bilgileri olmamasina rağmen, konu dikkatlerini çekti ve konuyu öğrendiler...'

ÖA40-K.'Siniftaki genel olarak iletişimi iyi idi. Fakat ve 'S ve $M$ ' isimli öğrenciler dikkatimi çekti. Gözlem çalışmalarım sırasında, S'nin bu sınıfa yeni geldiğini ve algılama sorunlarının olduğunu; M'nin ise ders sırasında çok ilgisiz olduğunu fark ettim. Ayrıca konuşurken kendini rahatça ifade ediyor olmasına karşın, sosyal ortamda arkadaşlarılla iletişim kurarken sorunlar yaşadığıı gözlemledim. Bu durum onun genel olarak derse ilgisiz olmasina ve simıttan uzak durmasina neden oluyordu. Öğrenci D'de de ayn problemleri gözlemledim. Neredeyse sinıfla hiç iletişim kurmuyordu. Bu nedenle onlarm arkadaşlık kurmaların sağlayacak bir etkinlik planı hazırladım. Arkadaşlık temalı bir fabl seçtim. Etkinlik sırasında 'maskeler, kartondan elma ağacı, hayvan kuklaları, renkli zarflar' kullandım. Seçtiğim fabl öğrencilerin arkadaşlık ilişkilerinde yaşadıkları problemleri fark etmelerini sağladı. Bu etkinlikle arkadaşlı̆̆ın önemi konusunda konuştuk. Etkinlik sırasında 'arkadaşlarını sevme, başkalarına saygı gösterme' konuları üzerinde durduk. Ders sonunda dağıttığımı çalışma kâğıtlarına hayallerini yazmaların ve düşüncelerini anlatmalarım istedik. Çalışmamızın nitelikli ve yararlı bir çalışma olduğunu söylemek istiyorum. Çünkü sınıftan çıkarken hepimizin yüzü gülüyordu...'

\section{Öğretmen adayı açısından}

ÖA2-E. 'Çocuk edebiyatı türlerini içine alan bir çocuk dergisi hazırladık. Öğrencilerle birlikte bir de gazete hatırladık ve sinıf köşesine astık. Keyif verici bir çalışma oldu. Daha önce ben de böyle bir çalışma yapmadığım için keyif aldım ve mutlu oldum. Ilk kez kendimi bir öğretmen olarak hissettim. 
ÖA8-K.'Çocuklarla çok iyi iletişim kurduk. Masal konusunda yaptığımız açıklamaları dikkatli bir şekilde dinlediler. Hazırladığımız materyal ile sunumuza başlarken, çalışmanın sonunda masalla ilgili (masalımı Pinokyo idi) sorular soracağımızı belirttiğimiz için çok dikkatli bir şekilde dersi takip ettiler. Masal anlatımına geçmeden önce 'Biz Tam Yedi Cüceyiz' şarkısını çocuklarla birlikte söyleyerek dans ettik. Döner TV ünitesi şeklinde bir okuma materyali hazırladık. Masal okuma etkinliği için hazırladığımız materyali kullanırken öğrencilerin dikkatini çok kolay bir şekilde çekebildiğimizi fark ettim. Değerlendirme esnasında, bir kutu içine koyduğumuz ve renkli kâğıtlar şeklinde yazdığımız soruları cevaplandırırken öğrenciler çok eğlendiler. Kutudan çektikleri soruları cevapladıktan sonra cevabını tahtaya yazdılar. Dersin başında öğrenciler cevap vermekten çekinseler de, etkinlikler sırasinda daha rahat hissetmeye başladılar ve derse daha çok katılım göstermeye başladılar. Bütün olarak değerlendirdiğimde Çocuk Edebiyatı dersinde teorisini gördüğümüz şeyleri uygulama imkânı bulduğum için bu çalışmanın bana çok büyük katkılarının olduğunu düşünüyorum. Çocukların iletişim becerilerini geliştirecek ve çocukların aktif olarak katılım gösterebilecekleri bu tür etkinliklerin yapılması bence çok önemli.'

ÖA11-K. 'Mesleğe başlayınca öğrencinin ilgisini çektiğini gördüğüm için materyal kullanmaya çalışacağım. Lisans eğitimlerimiz sırasında daha çok uygulamaya yönelik bu tür çalışmalar yapılması gerektiğini düşünüyorum.'

ÖA14-K. 'Çocuklar için çok yararl ve etkili bir etkinlik oldu. Öğrencilerle iletişim içindeydik. Çocuklar çok sevindiler, etkinliklere epey katılım gösterdiler. Materyalimiz de oldukça dikkat çekici ve öğretici idi. Kendimi bir öğretmen gibi hissettim. Tekrar böyle bir çalışma olsa katılmak isterim.'

ÖA20-K. 'Bu benim ilk öğretmenlik deneyimim oldu. Onlarla iyi bir iletişim kurabildiğ̈imi görebildim. Etkinliği oyunlaştırarak eğlenceli hale getirmeye çalıştım. Jest ve mimiklerimi de kullanmaya özen gösterirken, çocukları onaylayan 'aferin, harika, oo ne kadar da güzel, teşekkür ederim' gibi sözlerle onları motive ettim. Tatl bir heyecan içimi kapladı ve sunum bitinceye kadar devam etti. Etkinlikler sırasında ben de çocuklar da çok eğlendik ve mutlu olduk.'

ÖA31-K. 'Enerjisi oldukça yüksek bir katılım gösterdiler sinıftaki öğrenciler. Sorulara verdikleri cevaplar güzeldi. Bazı öğrencilerin kendilerini ifade ediş tavırları hoşuma gitti. Bazı öğrencilerinin de efendi tavırları, söz hakkı isteme davranışı ve kibarlı̆̆ dikkatimi çekti ve bu olumlu davranışları örnek gösterdim. Sinıftaki sıcak ortam öğretmenlik mesleğine daha çok bağlanmamı sağladı. Elimden geldiğince tüm öğrencilere söz hakk vermeye çalıştım. Öğrencilerimizden aldığımız olumlu tepkiler, bizleri hep hatırlayacaklarım söylemeleri ve onlara adaletli davrandığımızı söylemiş olmaları beni gururlandırdı ve geleceğe olan inancımı artırdı.'

ÖA41-K. 'Konumuz efsane idi. Renkli kartonlarla maketler hazırladik. Etkinlik sirasinda efsane kutusu ve kavram kartlarmdan yararlandik. Çocuklar dersi ilgiyle izlediler ve katılım gösterdiler. Çok güzel bir zaman geçirdim. Öğrencilerin ilgisi hoşuma gitti. Öğretmen olmanın ne demek olduğunu bizzat yaşadım. Çocuklara yeni bilgiler öğretmek çok heyecan vericiydi. Sınıfa girdiğimiz andan itibaren çocuklarm bize sevgilerini göstermeleri beni mutlu etti. Bu tür etkinliklerin daha sık yapılmasını isterim. Hem öğrenciler hem de biz öğretmen adayları açısından çok faydalı bir çalışma oldu. Biz de öğretirken eğlendik.'

\section{Tartışma ve Sonuç}

Günümüzde çocuk edebiyatı sadece bir eğitim aracı olmayıp, çocuğa okuma alışkanlığı kazandırmayı amaçlayan aynı zamanda çocuğun kendini bireysel anlamda 
gerçekleştirmesine yardım eden ve dilsel gelişimine katkısı olduğu kabul edilen bir edebiyat alanı olarak çocuk eğitiminde önemli bir konuma yerleşmiştir.

Çağdaş eğitim anlayışına göre çocuk edebiyatı ve eğitimin kesişim noktası çocuktur. $\mathrm{Bu}$ nedenle de çocuk edebiyatı ve çocuk eğitimi birbirleriyle yakın iki alan olarak düşünülmekte ve birbirini tamamlayan alanlar olarak ele alınmaktadır (Kıbrıs, 2010; Oğuzkan, 2010). Çünkü nasıl ki çağdaş eğitim anlayışının merkezi çocuk ise, çocuk edebiyatının da merkezi çocuktur. Bu anlayışta çocukların bireysel farklılıklarının göz önünde bulundurulması ve bilişsel, duyuşsal, psikomotor gelişim alanlarını destekleyecek uygulamalara yer verilmesi önerilmektedir (Güleryüz, 2006). Bu açıdan çocuk edebiyatı kapsamında ele alınan tüm kaynaklar çocuk eğitiminin nasıl ve ne şekilde yapılması gerektiği konusunda önemli rehberler olarak görülmektedir (Şimşek, 2003).

Çocuk edebiyatının amacı çocukların duygu, düşünce ve hayallerini çocukların dünyasına özgü bir anlatımla sunarken, çocuklara estetik bakış açısı kazandırmak ve çocukların bakış açılarını geliştirmektir (Oğuzkan, 2010; Sever, 2003). Çocuk edebiyatı türleriyle buluşan çocuk farklı biçimlerde kendisine sunulan olayları/olguları algılama ve anlamlandırmaya çalışırken, "estetik" açıdan farklı şekillere bürünmüş eserlerle de tanışmış olur ve farklı türleri okumaya ilgi duymaya başlar (Güleryüz, 2006). Hayal kurmayı, düşünmeyi, kendini ifade etmeyi öğrendiği gibi empatik süreçler sonunda başkalarının da duygu, düşünce ve hayallerini fark eder süreçlerden geçerken çocuk gündelik yaşamda insanlarla nasıl ilişkiler kurması gerektiğini sezerek öğrenir (Gönen \& Veziroğlu, 2017). Bu nedenle çocuk edebiyatı kapsamında ele alının 'masal, hikâye, mit, efsane, destan, şiir, öykü' gibi türlerin etkili eğitim aracı olarak işlev gördüğü söylenebilir (Oğuzkan, 2010). Ninniler, bilmeceler, tekerlemeler, yakıştırmacalar, türküler, çocuk oyunları gibi çocuk edebiyatı kaynakları ise çocukların iletişim süreçlerinde kendilerini daha iyi ifade edebilmesi için araçlar olarak kullanıldığında, çocuklara temel dil becerileri kazandırmada eğitici olduğu kadar eğlendirici araçlar olarak işlevler üstlenir (Güleryüz, 2010; Kıbrıs, 2010). Ayrıca kendilerini ifade etmelerini kolaylaştırması ve iletişim becerilerini geliştirilmesi sebebiyle eğitici bir araç olarak çocuk edebiyatı türlerinden yararlanılabilir. Dolayısıyla çocuk edebiyatı türleri ve kaynakları çocukların hem bireysel olarak doğal gereksinimlerinin karşılanmasında ve hem de onlara eğitsel ortamlar hazırlanmasında önemli bir rol oynadığı söylenebilir (Baş, 2015). 
Literatür incelendiğinde çocuk edebiyatı türlerinin eğitici bir araç kullanımı konusunda çok az sayıda araştırma yapıldığı ve bu çalışmalarda da öğretmenlerin çocuk edebiyatı ürünlerinden yeterince yararlanamadıkları anlaşılmaktadır (Balcı, 2012; Kuran \& Ersözlü, 2009; Maltepe, 2009). Örneğin Kuran \& Ersözlü (2009) sınıf öğretmenleriyle yaptıkları araştırmalarında öğretmenlerin çocuk edebiyatının edebiyattan farklı olan yönleri olduğunu bildiklerini ve derslerde çocuk edebiyatı ürünlerinden nasıl yararlanacakları konusunda bilinçli ve istekli olduklarına işaret etmekle birlikte, öğretmenlerin çocuk edebiyatı ürünlerinden nasıl yararlandıklarını ortaya koyamamıştır. Bu sonuçlar gerek öğretmenlerin ve gerekse öğretmen adaylarının çocuk edebiyatı türlerini seçip, uygulayabilme yeterliliklerinin incelenmesi gerektiğini göstermektedir.

Maltepe (2009) ise Türkçe öğretmeni adaylarıyla gerçekleştirdiği araştırmasında adayların Çocuk Edebiyatı ürünlerini seçebilme yeterliklerini belirlemeye çalışmıştır. Araştırma sonunda öğretmen adaylarının daha çok görsel ögelere (özellikle resimlere), yazı karakteri, basım özellikleri ve punto büyüklügü gibi unsurlara dikkat etmekle beraber, bu unsurların nasıl olması gerektiği konusunda ayrıntılı bilgi sahibi olmadığını göstermiştir. Araştırma sonucunda öğretmen adaylarının çocuk edebiyatı ürünlerini seçerken içerik, dil ve üsluptan çok, görsel ögeler, resimlerin daha etkili olduğuna inandıklarını ortaya koymuştur. Ayrıca öğretmen adaylarının çocuk edebiyatı dersin teorik bir ders olarak işlenmesini eleştirdiklerini tespit etmiştir. Bu bulguya dayanarak Türkçe öğretimi sürecinde önemli bir işlevi olduğunu ileri sürerek lisans düzeyinde verilen çocuk edebiyatı dersinin 2 saat uygulama ve 2 saat teorik olacak şekilde dönüştürülmesi gerektiğine işaret etmiştir.

Baş (2015) sınıf öğretmeni, okul öncesi öğretmenleri ile Türkçe dersi branş öğretmenlerinin dile dayalı temel becerilerin öğretilmesinde çocuk edebiyatından özellikle yararlanılması gerektiğine işaret ederek Türkçe öğretiminin niteliğinin, öğretmenlerin çocuk edebiyatından yararlanma düzeyiyle ilişkili olduğunu vurgulamıştır. Ancak çocuk edebiyatı türleri Türkçe eğitimi, okuma yazma eğitimi, matematik öğretimi, fen öğretimi gibi derslerde de öğretim amaçlı kullanılabilir. Bu nedenle sınıf öğretmeni yetiştiren eğitim fakültelerinde farklı derslerde çocuk edebiyatı ve çocuk eğitimi konulu uygulamalı çalışmaların yapılması yararlı olabilir. Bu yolla öğretmen yetiştiren fakültelerin Türkçe, sınıf öğretmenliği, okul öncesi öğretmenliği, sosyal bilgiler öğretmenliği gibi farklı bölümlerinde verilmesi gereken çocuk edebiyatı dersinin çıtıları incelenebilir. Özellikle sınıf öğretmenliği bölümlerinde okuyan öğrencilere Türkçe eğitimi, okuma yazma eğitimi gibi derslerde çocuk edebiyatından 
ne şekilde yararlanabilecekleri noktasında uygulamalar yaptırılması öğretmen adaylarının öğretmenlik mesleğine hazırlanmaları noktasında yararlı olabilir. Ayrıca sınıf öğretmeni yetiştiren eğitim fakülteleri düzeyinde uygulamalı çocuk edebiyatı dersinin çıktılarını saptamaya yönelik çalışmaların yapılması uygulayıcılara, politika yapıcılara ve araştırmacılara yol gösterici olabilir. Bu düşünceden hareketle bu çalışmada sınıf öğretmenliği ana bilim dalında lisans düzeyinde verilen çocuk edebiyatı dersi sadece teorik işlenmeyip, uygulamalı çocuk edebiyatı eğitimi programı uygulandıktan sonra; adayların ilkokul 3. sınıf düzeyinde Türkçe dersi için hazırlayıp uyguladıkları çocuk edebiyatı etkinliklerinin etkililiği değerlendirilmek istenmiştir. Uygulamalar 14 öğrencisi olan ve sınıfında iletişim sorunları olduğunu belirten bir ilkokul öğretmeninin sınıfında Türkçe dersinde 12 hafta süreyle öğretmen adayları tarafından yürütülmüştür.

Araştırma bulguları "Çocuk Edebiyatı Etkinliklerinin Değerlendirilmesi (Süreç)" ve “Çocuk Edebiyatı Etkinliklerinin Etkililiğinin Değerlendirilmesine İlişkin Görüşler (Sonuç)” olmak üzere iki başlık altında incelenmiştir. Birinci temada süreç değerlendirmesi yapılırken $2 \mathrm{~A}$ ve $2 \mathrm{~B}$ şubesinden gönüllü olarak araştırmaya destek veren öğretmen adaylarının 12 hafta süresince 3-4 kişilik gruplar halinde hazırladıkları çalışmalar, uygulamaların her adımında onlara rehberlik eden ve çocuk edebiyatı dersinin öğretimini de gerçekleştiren araştırmacı tarafından incelenmiştir. Süreçte yapılan çalışmaların incelendiği bu başlıkta öğretmen adaylarının çocuk edebiyatının amaçlarını planlama ve uygulama konusundaki yeterlilikleri değerlendirilmiştir. Öğretmen adaylarının süreçte gerçekleştirdikleri çalışmalara bakıldığında çocuk edebiyatı türlerini uygularken, "soru-cevap, gösterip-yaptırma, drama, oyun, örnek olay“ gibi yöntem ve tekniklerden yararlandıkları belirlenmiştir. Öğretmen adaylarının etkinlikler sırasında öğrencilerin dikkatlerini çekebilmek ve öğrenmelerini kolaylaştırabilmek için "görsel-işitsel öğretmen yapımı materyaller" kullandıkları ve uygulamalar sırasında öğrenirken eğlenmelerini de sağlamaya çalıştıkları tespit edilmiştir. Her bir etkinlik sonrası süreci değerlendirirken hedeflenen kazanımlara ulaşma derecesini kontrol etmeye özen gösterirken, "akran değerlendirme ve öz değerlendirme“tekniklerine de başvurdukları görülmüştür. Her iki şubeden katılan öğretmen adaylarının hazırlayıp, uyguladıkları etkinlikler genel olarak değerlendirildiğinde her bir etkinliğin " Çocuk Edebiyatı" dersinin amacına uygun olduğu, öğretmen adaylarının etkinliklerde farklı yöntem ve tekniklerden ile materyallerden yararlandıkları, hedefler yönünden öğrencilerin düzeylerini değerlendirebildikleri anlaşılmıştır. 
İkinci temada çocuk edebiyatı etkinliklerinin etkililiği konusunda sınıf öğretmeninin ve öğretmen adaylarının sonuç değerlendirmeleri iki alt tema halinde incelenmiştir. Sınıf öğretmeninin görüşlerine bakıldığında öğretmen adaylarının gerçekleştirdikleri uygulamaları "yararlı, etkili ve verimli" olarak değerlendirdiği tespit edilmiştir. Sınıf öğretmeni öğretmen adaylarının her birinin etkinliklerin sunumunu başarılı bir şekilde yerine getirdiklerini, etkili ve farklı materyaller kullanmaya özen gösterdiklerini, öğrencilerin derse olan ilgilerini artırabildiklerini ve öğrencilerle iletişim kurabildiklerini; neredeyse tüm öğrencilerinin çocuk edebiyatı türlerine olan ilgisinin arttığını dolayısıyla, okumaya karşı daha istekli tutumlar geliştirdiklerini belirttiği anlaşılmıştır.

Öğretmen adaylarının görüşlerine bakıldığında çalışmayı “öğrenci açısından ve öğretmen adayı açısından“ olmak üzere iki başlıkta değerlendirdikleri anlaşılmıştır. Öğrenci açısından genel olarak çalışmayı "etkili, yararlı ve nitelikli“ olarak değerlendiren öğretmen adaylarının çalışmayı kişisel açıdan da "keyifli, eğlenceli ve yararlı buldukları" tespit edilmiştir. Öğretmen adaylarının etkinlikler sırasında öğrencileri bilgilendirirken, eğlendirebildiklerini, güdüleyebildiklerini bu açıdan da hem kendilerinin ve sınıftaki öğrencilerin mutlu olduğunu hissettiklerini ifade ettikleri anlaşılmıştır. Araştırma bulgularına dayanarak öğretmen adaylarının ders öğretim elemanının rehberliğinde hazırlayıp, sınıf öğretmeninin gözetiminde uyguladıkları çocuk edebiyatı etkinliklerinin uygulama açısından başarılı olduğu ileri sürülebilir. Bu çalışma kapsamında ders öğretim elemanının rehberliğinde çocuk edebiyatı etkinliklerini hazırlayan öğretmen adaylarının, nitelikli planlar hazırlayabildikleri söylenebilir. Ders öğretim elemanın rehberliğinde ve sınıf öğretmeninin gözetiminde gerçekleştiren uygulamalar sırasında da "bilgilendirici, eğlendirici, dikkat çekici“ unsurlara yer vererek çocuk edebiyatı ürünlerini eğitim amaçlı kullanırken uygulamayı yaptıkları sınıfta öğrenci davranışlarını olumlu yönde etkileyebildikleri ileri sürülebilir.

\section{Uygulayıcilara Öneriler}

1. İlkokul düzeyinde çocukların okumaya karşı daha olumlu tutumlar geliştirmeleri ve çocukların çocuk edebiyatına olan ilgileri artırılmak isteniyorsa bu uygulamada olduğu gibi öğrenme sürecinde materyal kullanımına da özen gösterilerek “bilgilendirici, eğlendirici, dikkat çekici“ unsunlar da göz önünde bulundurularak çocuk edebiyatı türlerine yer verilmesi önerilebilir. 
2. Bu çalışma ile sınıf öğretmeni adaylarının çocuk edebiyatı dersinin amaçlarının farkında oldukları, amaçlara uygun etkinlikler tasarlayıp, uygulayabildikleri ve etkinliklerin nitelikli olduğu sonucuna ulaşılmıştır. Bu nedenle eğitim fakültelerinde lisans düzeyinde verilen çocuk edebiyatı dersinin de sadece teorik işlenmeyip, uygulamalı işlenmesi yararlı olabilir. Bu çalışmada olduğu gibi çocuk edebiyatına yönelik türlerin ve kaynakların nasıl kullanabileceği konusunda öğretmen adaylarına uygulamalı eğitimler verilmesi önerilebilir. Bu yolla ileride ilkokullarda görev yapacak öğretmen adayları çocuk edebiyatı kaynaklarının eğitim amaçlı kullanabileceğini hizmet öncesi dönemde deneyimleyebilir. Ayrıca çocukların ilgi ve gereksinimlerini göz önünde bulundurarak Türkçe dersinde çocuk edebiyatı ürünlerine yönelik etkinlikleri nasıl tasarlanıp, uygulanacağını öğrenebilir.

3. Bu çalışmada okuttuğu sınıf düzeyinde öğrenciler arasında iletişim sorunu olan bir sınıf öğretmeniyle gözlem ve görüşmeler yapıldıktan sonra, çocuk edebiyatı dersini alan öğretmen adayları ders öğretim elemanının rehberliğinde çocuk edebiyatı türlerini içine alan 3. sınıf düzeyinde Türkçe ders etkinlikleri hazırlamış ve sınıf öğretmeninin gözetiminde uygulamıştır. Araştırma sonucunda sınıf öğretmeninin öğretmen adaylarının uyguladıkları çocuk edebiyatı etkinlikleri "yararlı ve verimli" bulduğu ve öğretmen adaylarının uygulamalar sırasında sınıfındaki öğrencilerin davranışlarını olumlu yönde değiştirme konusunda başarılı olduklarını belirttiği sonucuna ulaşılmıştır. $\mathrm{Bu}$ nedenle sınıf öğretmenlerine de çocuk edebiyatı ürünlerinden nasıl yararlanabileceği konusunda yeterliliklerini geliştirebilecekleri hizmet içi eğitimler verilebilir.

Araştırmacılara Öneriler

1. Farklı derslerde çocuk edebiyatının uygulamadaki etkisini ortaya koyabilmek için farklı örneklem gruplarıyla nicel betimsel veya nitel olgusal araştırmalar yapılması yararlı olabilir.

2. Nitel araştırmalar gerçekleştirilerek farklı kademelerde öğretmenlerin başarılı uygulamaları araştırılarak, bu öğretmenlerin çocuk edebiyatından eğitim amaçlı yararlanırken nelere dikkat ettikleri (yöntem, araç-gereç, değerlendirme vs.) ortaya konulabilir. 
Bu çalışmada öğretmen adayları Türkçe dersinde 3. sınıf düzeyinde çocuk edebiyatı ürünlerine yönelik etkinlikler düzenlerken öğrencilere olumlu tutumlar kazandırmaya çalışmıştır. Etkinlik sonrası yapılan sınıf öğretmeni ve öğretmen adaylarıyla yapılan görüşmeler sonrasında öğrenciler ve öğretmen adayları açısından uygulamanın etkililiği tartışılmıştır. Araştırmanın sonuç değerlendirmeleri kısmında davranış değiştirmede çocuk edebiyatı türlerinin kullanımının sonuçları ortaya konulmaya çalışılmıştır. Bu araştırmadan hareketle farklı kademelerde (okul öncesi, ilkokul, ortaokul gibi) çocuk edebiyatı ürünlerinin davranış değiştirmede etkisini ortaya koyacak çalışmalar yapılabilir. Özellikle iletişim ya da davranış sorunları olan çocukların eğitiminde çocuk edebiyatı türleri ve kaynaklarının eğitim amaçlı olarak kullanılabileceğine örnek oluşturmak için nitel (tek denekli durum çalışmaları) araştırmalar yapılabilir. Birden fazla öğrencinin olduğu gruplarda ise öğrenci davranışlarının ne yönde değiştiğini saptayabilmek için nicel (yarı deneysel desen) yapılarak araştırma sonuçları tartışılabilir.

\section{Bilgilendirme}

Bu çalışma Uluslararası Temel Eğitim Kongresi'nde (2019) sözlü bildiri olarak sunulmuştur. Bu çalışmada kullanılan veriler 2020 yılı öncesine ait olduğu araştırmacı tarafından onaylanmıştır.

Yazar Katkı Beyanı

Kısmet DELIVELI: Öğretmen Yetiştirme Amaçlı Uygulamalı Çocuk Edebiyatı Konulu Bir Program Geliştirme, Yarı Yapılandırılmış Görüşme Formu Geliştirme ve Uygulama, Dokuman Analizi, İçerik Analizi ve Betimsel Analiz Yöntemiyle Bulguları Sunma ve Yorumlama, Araştırma Sonuçların Yazma ve Öneriler Geliştirme.

\section{Kaynaklar}

Altunya, H. (2012). Türk çocuk edebiyatı kaynakçası. Ankara Üniversitesi Çocuk ve Gençlik Edebiyatı Uygulama ve Araştırma Merkezi.

Arseven, T. (2005). Mesaj açısından çocuk kitapları, Hece Çocuk Edebiyatı Özel Sayısı, 104-105.

Bağcı, H. (2007). Türkçe öğretmeni adaylarının çocuk edebiyatına ve çocuk edebiyatı dersine yönelik tutumlarının değerlendirilmesi, Milli Ĕ̆itim Dergisi, 174.

Balcı, A. (2012). Türkiye'de çocuk edebiyatı üzerine hazırlanan lisansüstü tezler hakkında bir meta-analiz çalışması. Mustafa Kemal Üniversitesi Sosyal Bilimler Enstitüsü Dergisi, 9(17), 195-206.

Balta, E. E. (2019). Çocuk edebiyatı üzerine yapılmış lisansüstü çalışmaların içerik analizi (2011-2018 Y1llar1). International Journal of Society Researches, 10(17), 1-26. 
Baş, B. (2015). Türkçe öğretimi açısından çocuk edebiyatı. Ankara: Pegem Akademi Yayınları.

Creswell, J. (2014). Nitel araştırma yöntemleri. (Gözden Geçirilmiş 2. Baskı), Ankara: Siyasal Kitabevi.

Gönen, M. \& Veziroğlu M. (2017). Çocuk edebiyatının genel hedefleri. T. Şimşek. (Ed.) içinde, Çocuk edebiyatı (ss. 1-13). Ankara: Eğiten Kitap.

Güleryüz, H. (2006). Yaratıcı çocuk edebiyatı. Ankara: Pegem A Yayıncılık.

Johnson, B. \& Christensen, L. (2014). Educational research: quantitative, qualitative and mixed approaches. ( $5^{\text {th }}$ edit) Boston: Pearson Education Inc.

Kıbrıs, İ. (2010). Uygulamalı çocuk edebiyatı. Ankara: Eylül Yayınları

Kuran, B. Ş. \& Ersözlü, Z. N. (2009). Sınıf öğretmenlerinin çocuk edebiyatına ilişkin görüşleri. Yüzüncü Yıl Üniversitesi Eğitim Fakültesi Dergisi, 6 (1), 1-17.

Lincoln, Y.S. \& Guba, E.G. (1985). Naturalistic inquiry. California: SAGE.

Maltepe, S. (2009). Türkçe öğretmeni adaylarının çocuk edebiyatı ürünlerini seçebilme yeterlilikleri, Balıkesir Üniversitesi Sosyal Bilimler Enstitüsü Dergisi,12(21), 398- 412.

Mattson, C. P. (2015). Children's literature grows up. A dissertation presented. Doctored Tesis of Philosophy, The Department of Comparative Literature, Harvard University.

Oğuzkan, A. F. (2010). Çocuk edebiyatı. Ankara: Anı Yayıncılık.

Patton, M. Q. (2014). Qualitative research and evaluation methods. Edts: M. Butun \& S. B. Demir. Ankara: PegemAkademi.

Sawyer, W. E. (2012). Growing up with literature. Abbany: Wadsworth.

Sever, S. (2003). Çocuk ve edebiyat. Ankara: Kök Yayıncılık.

Sınar, A. (2006). Türkiye'de çocuk edebiyatı çalışmaları, Türkiye Araştırmaları Literatür Dergisi, $4(7), 175-225$.

Şimşek, T. (2002). Çocuk edebiyatı. Ankara: Rengarenk Yayınları.

Yalçın, A. \& Aytaş, G. (2005). Çocuk edebiyatı. Ankara: Akçă̆ Yayınları.

Yıldırım, H., \& Şimşek, A. (2013). Sosyal bilimlerde araştırma yöntemleri. (Genişletilmiş 9. Basım), Ankara: Seçkin Yayıncılık.

Yin, R. K. (2011). Qualitative research from start to finish. New York: The Guilford Press. 